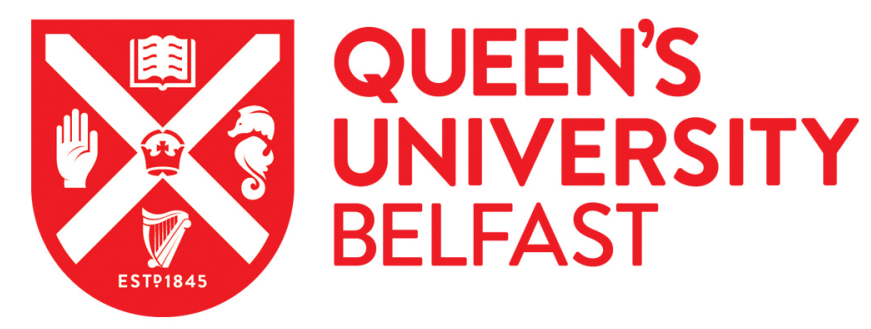

\title{
Immigration and the demand for life insurance: evidence from Canada, 1911
}

de Bromhead, A., \& Borowiecki, K. J. (2016). Immigration and the demand for life insurance: evidence from Canada, 1911. European Review of Economic History, 20(2), 147-175. https://doi.org/10.1093/ereh/hev022

\author{
Published in: \\ European Review of Economic History
}

\section{Document Version:}

Peer reviewed version

Queen's University Belfast - Research Portal:

Link to publication record in Queen's University Belfast Research Portal

\section{Publisher rights}

Copyright the author 2016 .

This is a pre-copy edited, author-produced PDF of an article accepted for publication in the European Review of Economic History following peer review. The version of record is available online at: http://ereh.oxfordjournals.org/content/20/2/147.

\section{General rights}

Copyright for the publications made accessible via the Queen's University Belfast Research Portal is retained by the author(s) and / or other copyright owners and it is a condition of accessing these publications that users recognise and abide by the legal requirements associated with these rights.

Take down policy

The Research Portal is Queen's institutional repository that provides access to Queen's research output. Every effort has been made to ensure that content in the Research Portal does not infringe any person's rights, or applicable UK laws. If you discover content in the Research Portal that you believe breaches copyright or violates any law, please contact openaccess@qub.ac.uk. 


\title{
Immigration and the demand for life insurance:
}

\section{Evidence from Canada, 1911}

\author{
Alan de Bromhead and Karol J. Borowiecki *
}

July 2015

\begin{abstract}
This paper analyses the determinants of the demand for life insurance using sample data from the 1911 Census of Canada. We find that immigrants' demand for life insurance was on average around 13 percentage points lower than that of native-born Canadians, with the effect varying by province of settlement. We interpret these findings as evidence suggesting a greater appetite for risk among self-selecting immigrants relative to native-born Canadians. We also uncover evidence of a slow assimilation of immigrants in terms of life insurance holdings, slower indeed than the process of assimilation in terms of earnings.
\end{abstract}

Keywords: Insurance, welfare, migration, Canada

JEL Classifications: G22, J61, N31

* Alan de Bromhead: Queen’s Management School, Queen’s University Belfast, Northern Ireland . E-mail: a.debromhead@qub.ac.uk. Karol Jan Borowiecki: University of Southern Denmark, Department of Business and Economics, Odense, Denmark. E-mail: kjb@sam.sdu.dk. 


\section{Introduction}

In the period from the turn of the $20^{\text {th }}$ century up to the beginning of the Great War, Canada experienced rapid economic growth and high levels of immigration. On average, Canadian GNP increased annually by 6.21 per cent over the period, representing the highest level of real output growth that the Canadian economy has ever experienced (McInnis, 2008). From the onset of the $20^{\text {th }}$ century until 1911, Canada's population expanded by more than 33 per cent, which was almost entirely due to the arrival of around $1.8 \mathrm{~m}$ immigrants (The Canada Yearbook, 1911). Those developments coincided with an equally remarkable growth of the Canadian insurance market, which became increasingly important for investment and the continued expansion of the Canadian economy, as well as for protecting households from increasing levels of income risk associated with growing urbanisation and industrialisation. The nominal value of life insurance policies in force increased by a factor of ten between 1875 and 1910 , while in the first decade of the $20^{\text {th }}$ century alone life insurance companies in Canada more than doubled their total assets (Canada Yearbook, 1911). An important element in understanding this growth is an appreciation of the factors that influenced the demand for life insurance among Canadian households and, in particular, what role immigration played in this process.

In this study we investigate the determinants of insurance demand and direct the focus on the issue of immigration. The time period under investigation is interesting, not only due to its remarkable population growth dynamics - in particular the very high share of new immigrants - but also as it creates a unique setting for research on risk attitudes of immigrants. It is also rare to have the opportunity to study household preferences free from any interference of government-provided insurance. In 1911 state sponsored substitutes for private insurance were unavailable and governmental involvement in the Canadian insurance market was only in a regulatory capacity. Furthermore, employers were unlikely to provide workers with life 
insurance (Di Matteo and Emery, 2002). Therefore the decision to purchase insurance at this point in time can be viewed as being based purely on private motivations.

The presence of formal financial services such as life insurance is often suggested as a crucial factor for growth of developing countries (Brainard, 2008). Insurance companies’ role is not only in the provision of investment funds, but also in increasing the efficiency of diversification of individual household risk. In the absence of well-developed insurance markets, households are forced to rely on sub-optimal informal insurance arrangements, such as holding cash savings or the accumulation of physical asset stocks (Rosenzweig, 2001). The availability of formal insurance can therefore provide a more efficient mechanism for poor households to pool idiosyncratic risk. Not surprisingly, the development of the insurance market in Canada during the late $19^{\text {th }}$ century was regarded of vital importance to Canadian development (Drummond, 1962).

The database used in this research is a five per cent representative sample of the population of Canada constructed by the Canadian Century Research Infrastructure (CCRI) and based on the 1911 Census. To the best of our knowledge, the underlying study is the first to use this large and comprehensive database for research on insurance holdings in Canada. The data set contains detailed records regarding holdings and value of life insurance as well as a wide selection of control variables, including the respondent's place of birth and, for immigrants, the date of arrival in Canada. Furthermore, the data records the province of birth and residence of Canadian-born respondents, which allows us to also identify internal migrants. It is important to note that enumerators were instructed to record life insurance holdings "whether in an old line company, an assessment company or fraternal organization" (Census and Statistics Office, 1911). The insurance variables therefore capture not only the contracts purchased from commercial providers but also from informal organizations, such as burial societies. This broad coverage of insurance providers therefore reduces the problem of pricing 
of insurance for migrants, as fraternal societies would likely have provided an alternative to formal contracts. ${ }^{1}$ Based on around 72,000 observations of household heads, we estimate the probability of holding life insurance as a function of the available control variables. ${ }^{2}$ We find that immigrants were around 12.8 percentage points less likely to purchase life insurance. The probability that an immigrant holds life insurance increases during the first forty years or so after immigration before it begins to fall. The findings provide an indication of the existence of a lower risk aversion among immigrants.

This study provides two main contributions. First, it adds to the large literature on immigration to the New World and assimilation of immigrants into North American labour markets. Hatton (1997), examining data from Michigan and California in the late $19^{\text {th }}$ century found that immigrants assimilated well in terms of earnings. Indeed for those immigrants that arrived as children, earnings were very similar to native-born workers once they reach adulthood, while adult immigrants from Britain actually earned more than the native-born in Michigan. The assimilation of immigrants to Canada in the early $20^{\text {th }}$ century has been examined by Green and MacKinnon (2001). They used a sample of the 1901 census to explore how quickly immigrants’ earnings caught up with those of native-born, English mother-tongue Canadians. Even though British migrants were seen as "invisible immigrants” (p.335), in that they faced the fewest barriers to assimilation such as language and legal system; nonetheless, English immigrants assimilated slowly and achieve earnings parity only 28 to 49 years after immigration. In this paper we show that there existed an even slower rate of assimilation in relation to the purchase of life insurance. This may indicate that differences between immigrants and native-born Canadians were attributable not only to cultural, economic and discriminatory factors, but are also possibly related to differing risk attitudes.

Second, this paper contributes to research on historical insurance holding. A study conducted by Di Matteo and Emery (2002) is of particular relevance to this analysis due to the 
common period and country under examination. The study investigates the relationship between personal wealth and demand for life insurance, based on male probated decedents in Ontario in 1892. Consistent with theoretical literature on the demand for life insurance, and contrary to the findings in much of the empirical literature, wealth accumulation was found to be a substitute for market purchases of life insurance. Di Matteo and Emery’s evidence suggests that households primarily demanded life insurance when they lacked accumulated reserves or wealth to provide self-insurance, often early in the life cycle. To some extent this study will draw on their analysis but will differ with respect to the specific research motivation and variables under scrutiny. The principal focus of this study is the relationship between insurance uptake and immigration. Any difference between the agrarian, newly settled West and the relatively urbanised East or Central Canada is also investigated. The additional information uncovered in this analysis can be combined with Di Matteo and Emery’s investigation and should help deepen the understanding of the determinants of insurance demand during this period in Canada.

The rest of this study is structured as follows. In section 2 a historical background of Canada in 1911 is presented. Section 3 reviews literature on the demand for life insurance, while Section 4 introduces the data used. The results of our analysis are presented in section 5, before Section 6 concludes.

\section{Canada in 1911}

The period from Confederation in 1867 to the beginning of the Great War was a time of significant economic and demographic change for Canada. The population more than doubled from 3.5 million in 1867 to 7.9 million by 1914. During the years 1901 to 1911 alone, the population grew from 5.4 million to 7.2 million. This growth was driven predominantly by 
high levels of immigration with an average annual immigration of around 150,000 over the period from 1901 to 1911 (Canada Yearbook, 1911, 1914). Immigrants came from all corners of the globe, but government immigration policy favoured settlers from European countries. ${ }^{3}$ The vast majority of new settlers came from the British Isles due to the strong cultural and economic links that existed between Britain and her former colony. A principal reason for the high levels of immigration was a concerted effort on behalf of the Canadian government to extend its control over the western provinces, particularly the Prairie provinces of Alberta, Saskatchewan and Manitoba, by encouraging settlement there. In an effort to achieve this goal, the government passed the Dominion Lands Act in 1872. The act outlined that lands were to be given to settlers in return for the payment of a $\$ 10$ fee and the performance of specified duties - e.g., building a habitable residence and cultivating a certain area annually (Regehr, 2011). Despite these efforts Canada actually experienced net emigration in the late $19^{\text {th }}$ century (Green and MacKinnon, 2001). However the “Golden age of Canadian development” (p.316) began at the turn of the $20^{\text {th }}$ century as immigration took off. Consequently the population of the Prairie provinces increased dramatically; the populations of Alberta and Saskatchewan increased by more than 400 per cent between 1901 and 1911 (Canada Yearbook, 1911). This increase, coupled with an expansion of the western railway network, led to an agricultural boom driven largely by the production of wheat. Canada became a major player on the world wheat markets with a 14 per cent share of world wheat exports in 1914 (Solberg, 1987 p.36). The country also became a significant exporter of animal products, fishery products and minerals (New York Times, 1912). However the boom was not only driven by agriculture, with domestic investment and manufacturing also contributing to rapid economic growth (Bothwell et al., 1990).

Alongside these rapidly expanding sectors, Canada’s financial sector grew alike. The insurance sector in Canada was well developed by the beginning of the $20^{\text {th }}$ century 
(Drummond, 1962). The value of life insurance in force in Canada rose from \$64 million (1900 Canadian dollars) in 1875 to $\$ 679$ million by 1910, while the total assets of Canadian life insurance companies rose from a value of \$118 million in 1901 to $\$ 212$ million by 1911 (Canada Yearbook, 1911). ${ }^{4}$ Total assets owned in 1911 by life insurance companies were valued 86 per cent higher than the assets owned by the Canadian State. In comparison to the manufacturing industry: assets owned by life insurance companies were valued at 29 per cent of the entire manufacturing sector in Canada (capitalisation of manufacturing firms was equal to $\$ 847$ million in 1911, Canada Yearbook, 1911).

Insurance companies were also a major player in capital markets, lending more money in mortgages in the decade before the Great War than the designated mortgage companies, while at the same time becoming heavily involved in the Canadian bond market (Drummond, 1962). The fact that the insurance industry in Canada had spread far and wide by the beginning of the $20^{\text {th }}$ century was noted by the author Arthur Granville Bradley:

Insurance is a very prominent business in Canada, and Toronto is one of its chief headquarters, sending out troops of agents over the whole country as far as the Pacific coast. I know there are insurance agents in England from modest notices hanging here or there on the walls of shop or office, but in Canada you may travel with a whole smoking compartment full of them, and dine at tables in hotels where there is no one else... I do not think there is a man of substance in Canada uninsured, not because prudence is a specially Canadian virtue, but in view of the number of insurance agents perennially on the warpath... (Bradley, 1903 p.225)

Despite this seemingly intense competition, the insurance market in Canada continued to be profitable. In 1910 the net income on premiums paid by the insured was equal to \$28.9 million (1900 Canadian dollars). A further \$8.9 million income was obtained from investments on the 
capital markets. The total cash income of life companies was equal to $\$ 39.7$ million which constitutes a remarkably high return on the companies' total assets of 18.7 per cent (Canada Yearbook, 1911).

The high profits earned by the life insurance companies led the public to believe that the accumulated premiums were not being invested in the best interests of the policy holders and that company directors were operating imprudently. As a result of this speculation a Royal Commission on Life Insurance Companies was established to investigate these claims in 1906. The commission found evidence of improper management of funds by the life insurance companies and recommended amendments to legislation to protect the policy holders' interests. The commission's report became the basis for the Insurance Act of 1910, which was designed to better regulate the growing Canadian insurance market (Bishop, 1912).

The number of Canadian life insurance companies grew rapidly over the last decades of the $19^{\text {th }}$ century, increasing from one company (Canada Life) in 1870 to seventeen in 1900 , although as in the US, the industry remained concentrated (Davis and Gallman, 2001 p.431; Keller, 1999). By 1911, the Canadian insurance market had a handful of dominant domestic players which operated alongside competitors from the United States and the United Kingdom. This competition induced Canadian companies to also increase their foreign operations. In 1914 some $40 \%$ of life insurance premiums were collected by foreign companies while Canadian life insurance companies received 32\% of their premium income from abroad (Drummond, 1962).

Life insurance in Canada was indeed an important financial asset, both as a form of income protection for households and to Canadian Capital markets as a source of funds for investment. The maturing of the population over the period of economic and geographic expansion increased the demand for insurance, while competition among the major companies boosted supply. As a result, the proportion of the population holding a life insurance policy 
steadily increased. According to Di Matteo and Emery (2002) 18 per cent of Canadian males held life insurance in 1901. Based on the five per cent census sample, 32 per cent of male household heads held life insurance by 1911 . When compared to other countries, the Canadian life insurance industry appears well developed relative to the most advanced economies of the time: the United States and the United Kingdom. Life insurance premiums per capita collected in Canada were only slightly lower than in the United Kingdom in $1911 .^{5}$

\section{Demand for Life Insurance}

The demand for life insurance has commonly been linked with the motivation to accumulate assets. Life insurance is judged to be an asset similar in form to savings and is as such, important to a household's life time utility maximisation strategy. The motivation to save or acquire insurance, as outlined by Di Matteo and Emery (2002), can be explained in three principal ways; the life-cycle motivation, the bequest motivation and the precautionary savings motivation. According to Di Matteo and Emery (2002 pp.450-453), the bequest motive is defined as the accumulation of assets during working years in order to provide offspring with an inheritance, while precautionary savings is defined as the accumulation of assets to deal with short-term unforeseen economic events. The life-cycle theory predicts that households wish to smooth consumption over their life time and that individuals accumulate assets during their working lives and consume these assets in retirement (Jappelli and Modigliani, 2006). The idea of a hump shaped wealth-age curve would imply that savings would be low, perhaps even negative, early on in the life cycle. This form of life-cycle asset accumulation behaviour has been identified by Di Matteo (1997) in Canadian data from the late $19^{\text {th }}$ century. Life-cycle savings motivations likely gained in importance as the number of individuals reaching retirement age increased over the course of the $19^{\text {th }}$ century. Indeed the transition to a "modern" 
definition of retirement may have taken place earlier than was once thought (Carter and Sutch, 1996).

\section{[Table 1 about here]}

This study has a particular focus on the potential difference in insurance demand between self-selecting migrants relative to non-migrants. On the one hand, demand for life insurance may be greater among immigrants as their potential for self-insurance would be diminished. Immigrants would likely have less capacity for informal risk sharing as private networks are often initially less extensive. On the other, demand for life insurance may be lower for immigrants if the individuals who emigrate have a below average level of risk aversion. Jaeger et al. (2010) show this to be the case for contemporary German migrants: individuals who are relatively willing to take risks show a significantly higher probability to migrate. The authors further suggest that the United States may enjoy a higher degree of labour mobility today in part due to the fact that it has experienced many waves of immigrants who are likely to have been risk takers. A study by Di Matteo (1996) of the wealth holdings of Irishborn and non-Irish-born in Ontario in 1892 finds no connection between birthplace and wealth overall, but there is an indication that the Irish-born were less likely to hold financial assets. Furthermore, Amuedo-Dorantes and Pozo (2002) find that immigrants have a lower propensity to accumulate precautionary savings, and it is possible that the demand for insurance follows a similar pattern. However, a decrease in precautionary savings may be due to the impact of remittances on saving capabilities. It might be expected then that the length of time since immigration would diminish the influence of both these effects, as more extensive family risk sharing networks evolve and immigrants become assimilated. A greater appreciation of attitudes towards risk among immigrants and their assimilation could therefore potentially lead to an improved understanding of differences in labour mobility across countries and over time. 
A number of factors that potentially influence the demand for life insurance have been identified; factors that would likely have been different for immigrants and native-born. Theories of insurance demand predict that insurance purchase is related to the motivation to preserve income streams, so that the individual can provide for himself and his family. Income streams could be interrupted by illness, accidents or other unforeseen economic hardships. Insurance can protect households from a collapse in their consumption that would otherwise follow a break of income. Savings, often referred to as self-insurance, could also provide this function. However, savings take time to accumulate, which for recent immigrants is a particular constraint. As such, immigrants might be expected to have greater need for insurance to substitute for savings. Likewise insurance would represent a better instrument by which to preserve future household consumption early in the life cycle and implies that insurance purchase would be negatively related to age (Hammond et al., 1967). The bequest motivation for the acquisition of life insurance can be seen as an extension of the life cycle motivation. As transfers across generations link the life cycle of the household head to that of its dependents, the relevant utility maximising economic agent may be the household itself and not the household head. The purchase of life insurance is seen as a transaction made on behalf of the insured dependents, where the principal intention is to provide offspring with an economic safety net of their own (Lewis, 1989). It is not clear that the bequest motivation would influence immigrants and native-born differently.

Household income is also considered to have a significant effect on the level of life insurance demand. The relationship between income and the demand for life insurance is, however, argued to be complex and depends on the degree of household risk aversion and how it changes with income (Cleeton and Zellner, 1993). Households in which the income of the household head represents the only stream of income would be expected to have a higher demand for life insurance while households with more than one income - and therefore less 
reliant on the income of the household head - would be likely to have less need to insure the household head (Di Matteo and Emery, 2002). This theory finds support in evidence provided by Duker (1969) and Kantor and Fishback (1996) with respect to the insurance demand of households with working wives. Since differences existed between the income and occupations of immigrant and native-born, we control for these variables in the empirical analysis.

A further variable that is considered to affect the level of life insurance demand is the level of education, as it is associated with a better understanding of the benefits of life insurance (Truett and Truett, 1990). A variable indicating whether the respondent could read and write is therefore included in the analysis, as is a variable indicating whether or not individual could speak an official language.

Whether the respondent lived in an urban area is also likely to have affected both the supply and demand for insurance. Those living in urban areas were more likely to be reliant on the labour income of the household head than farmers and farm-workers (Di Matteo and Emery, 2002), while access to insurance services would have been less costly for urban dwellers. Immigrants too tended to be concentrated in urban areas. To further examine the supply of insurance, a variable is created indicating the concentration of insurance agents and brokers within the census district. As local networks are expected to have been important to insurance agents in identifying potential customers, we also include a measure of the number of insurance agents and brokers of the same ethnicity as the individual that reside in the same district. The role of connections is also recognised by a contemporary source that gives advice to insurance agents in the USA: "The securing of an application depends upon the creation of confidence which may be difficult to effect in the case of an entire stranger” (Spectator Company, 1916, p. 33). As such we hope to capture an informal, yet potentially important, aspect of insurance supply that may have particular relevance for immigrants. ${ }^{6}$ 


\section{Data}

To estimate the demand for insurance in early $20^{\text {th }}$ century Canada, we make use of the five per cent sample of the 1911 census of Canada constructed by the Canadian Century Research Infrastructure (CCRI). The questions that make the 1911 Canadian Census unique and therefore facilitate our analysis are, of course, those relating to insurance. The enumerators were asked to record the details of an individual's life insurance holdings, namely the total value of the life insurance policies in force and the total cost per year of premiums on all insurance policies. The insurance holdings include both formal contracts signed with insurance providers and informal agreements entered with fraternal organisations, burial societies and similar institutions.

\section{[Table 2 about here]}

The sample consisting of data for household heads is summarised in Table 2. The first three columns describe native-born Canadians in the sample, while the last three provide information for the sub-sample of immigrants. ${ }^{7}$ Canadian-born individuals encompassed by the sample are in 91 per cent of cases male and have an average age of 45 years. 81 per cent of native-born household heads are reported as being married. The average number of dependent children that is, children aged 16 or under - is equal to 1.8 per household. Approximately 74 per cent of the sample was born in Canada while the remaining immigrated predominantly from England, followed by the United States, Scotland and Ireland. The sub-sample of immigrants reveals very similar characteristics to the native-born sample, with the main differences that immigrants were somewhat less likely to be married and had fewer dependent children. For immigrants the year of arrival in Canada was also recorded. The sample data indicate that the average number of years since immigration was around 11 years. The variables of most importance to this analysis are those concerning life insurance holdings. 31 per cent of the native-born sub-sample reported holding a life insurance policy with an average value of \$2029 
and an average annual premium of \$86. The proportion of immigrants’ holding life insurance is about 24 per cent. The average value of life insurance, as well as the premium for life insurance, are somewhat lower for immigrants than for those born in Canada, however the median value of an insurance policy was identical. ${ }^{8}$

The occupation of the household head is separated into twelve categories according to the classification method provided by the census authorities. There appears to be little difference between the occupational structure of immigrants and native-born Canadians, although there were likely to have been differences within these broad sectoral classifications. ${ }^{9}$ According to this classification, 45 per cent of the native-born sub-sample was recorded by the enumerator as working in agriculture. ${ }^{10}$ Tenant farmers and land-owning farmers had a degree of income risk protection, in so much as other members of the household could assist in farm work. As such, both types of farmers could avail of risk management and diversification techniques that to some extent decreased their exposure to income shocks (Stead, 2004). The direction of the influence of being a farmer on the demand for insurance might presumably be expected to be similar for both tenant and land-owning farmers. Additionally, farm land can be seen as an asset and hence a land-owning farmer could rely on that land as a substitute asset to insurance, therefore having less need for formal insurance contracts. ${ }^{11}$ The sub-sample of immigrants discloses a somewhat lower share of farmers than the sample as a whole. As the title "farmer" tells us little of the economic position of the household head, in the analysis that follows a variable is constructed that identifies farmers that were self-employed and also employed others, in this way separating farmers that were likely to have been more affluent from poorer farmers.

In this study, in addition to occupation controls, we have records that indicate the total household income for 57 per cent of households. ${ }^{12}$ Interestingly, incomes are higher on average for immigrants than for native-born Canadians. As farmers did not usually report income on 
their returns, the data on income is somewhat biased towards non-farmers, who were more likely to purchase a life insurance policy. A similar problem is encountered by Di Matteo and Emery (2002), who do not have any income records and are forced to rely on the occupation variables that provide some approximation for the missing variable. For immigrants, the income of the household head contributed, on average, $76 \%$ of total household income, while for native-born this figure was $82 \%$.

Panel E reveals that both native-born Canadians and immigrants were highly literate. 86 per cent of immigrants spoke English. Only 5 per cent spoke French compared to 32 per cent for the native-born. The greatest differences between the native-born sub-sample and the sub-sample of immigrants can be observed with respect to religion (Panel F). Catholics are the most numerous group in the full sample, with the rest being mainly Methodists, Presbyterians or Anglicans. Immigration from other countries such as Catholic France was much less significant. Consistently, the sub-sample of immigrants includes fewer Catholics and more Anglicans, Lutherans, Jews and other religions. Settlement patterns also differed between the native born and the immigrant population. Immigrants were more likely to live in urban areas and were more concentrated in the western provinces of Alberta, British Columbia, Manitoba and Saskatchewan. These geographical differences and whether this is related to the demand for life insurance will be explored in more detail in the next section.

\section{Empirics}

In order to uncover the factors influencing whether a household head possessed a life insurance policy in Canada in 1911, a binary response approach is required. In this formulation the outcome of the discrete choice, to hold an insurance policy or not, is viewed as a reflection of 
an underlying Probit model. The model is estimated using Maximum Likelihood Estimation, and marginal effects are computed at the means of the independent variables. ${ }^{13}$

The results are presented in columns (1) to (4) of Table 3. The first column summarises the point estimates for a regression with a set of control variables that potentially influence the decision to obtain life insurance, as has been discussed in section 3. Of main interest is the indicator function Immigrant, which takes the value one if the individual immigrated to Canada as an adult and zero otherwise. ${ }^{14}$ The point estimate is highly significant and indicates that immigrants were about 12.8 percentage points less likely to hold life insurance than nativeborn Canadians, all else being equal. It can be also observed that the remaining control variables remain consistent with expectations and previous research; in particular with Di Matteo and Emery (2002). The probability of holding life insurance increases if the head of the household is male or married. The estimated coefficients on the quadratic age polynomial indicate that the probability of holding life insurance increases with age, albeit at a decreasing rate. ${ }^{15}$ Each additional dependent child (aged 16 or under) is not statistically related to the probability of holding life insurance. One may speculate that the absence of a significant association is due to the presence of more than one contradictory forces at play. On one hand, having more children is a substitute for insurance (as children can provide support for parents in old age), leading to lower insurance demand. On the other, having children makes your life more valuable (as one needs to cater for children; children are also those who obtain the insurance payment in case of death), therefore higher demand for insurance. A further exploration of this finding, although interesting, lies however beyond the scope of this paper. ${ }^{16}$

\section{[Table 3 about here]}

Being able to read and write increases the probability of holding life insurance by around 18 percentage points. A higher probability is also observed for those who speak an official language or live in urban agglomerations. ${ }^{17}$ The probability of holding life insurance 
increases with income at a decreasing rate, while the probability of holding life insurance is higher for most professional categories compared to employment in agriculture, the baseline category (not reported). ${ }^{18}$ Being a self-employed farmer-employer has an insignificant effect on the demand for life insurance. ${ }^{19}$ The point estimate for the introduced insurance supply proxy is positive and statistically significant. This indicates that having more insurance agents of the same ethnicity in your district increased the probability that you held life insurance. This is indeed an interesting result as it suggests that agents were recruiting from within their own ethnic groups. Furthermore, the result provides support for the advice given to insurance agents by the Spectator Company (1916, p. 33) that “connection is a valuable factor" in finding prospective insurance buyers. Finally, the regression also includes a set of indicators for each province with Ontario as the reference category (not reported). ${ }^{20}$

Next, we estimate a further regression with a set of controls for the country of birth. We use Canadian-born individuals as the base category and a set of indicator functions for the remaining countries of origin. In column (2), the coefficients on country of origin are always negative and statistically significant. The smallest marginal effects of between four and eight percentage points are found for individuals born in Scotland, Ireland, the USA and England. This is followed by Germany (12.6\%), Sweden (17.0\%), the Rest of Europe and Rest of World categories (each ca. 18\%), while the remaining countries for which we have a reasonable number of observations are 30 percentage points below the probability of holding insurance by Canadians. One could suspect that the results are to some extent affected by unobserved preferences and social norms with regard to insurance demand that may differ across countries and cultures. However, given the significant difference between immigrants born in the USA and Canada, and the high degree of similarity between these two countries, we believe, the results are attributable to more than simply to unobserved cultural differences, and interpret them as being suggestive of a lower level of risk aversion among immigrants. Furthermore, the 
relatively small difference for the USA and the British Isles compared to other parts of the world might be reflective of the fact that cultural and geographic distance are also important. The remaining variables in this model are consistent with the specification presented in column (1).

In column (3), further controls for religious background of the respondent are included. This step is motivated by Di Matteo and Emery (2002) who found heterogeneity in insurance demand depending on religious background. The authors speculate that Roman Catholics might have been less well-informed about the benefits of life insurance, as they were somewhat less literate than the average, and hence would demand less insurance. Since in our model we account for literacy, this argument does not apply. ${ }^{21}$ Furthermore, since Anglican and Protestants were substantially more influential in the banking and finance sector, it could be further the case that they are more aware of the diversification advantages of the life insurance asset, although a confirmation of this explanation is unfortunately not possible in our specification. The influence of religion on the probability of holding life insurance is positive and statistically significant only for Methodists, Baptists and Presbyterians, with Roman Catholics as the base category. The results also indicate that Jews and Lutherans demanded less insurance than Catholics, whereas Anglican and Protestants exhibit insurance demand that is indistinguishable from Catholics. Nonetheless, most importantly for the aim of this paper, it can be also be observed that in this specification the coefficient for immigrants remains very consistent in sign, size and significance compared with the baseline model from column (1). This supports the view that demand for insurance is influenced by whether the individual was a migrant or Canadian-born.

Each specification so far includes individual province fixed effects. In column (4) we group all nine covered provinces into three regions: the East (Nova Scotia, Prince Edward Island and New Brunswick), the Center (Quebec and Ontario) and the West (Manitoba, 
Saskatchewan, Alberta and British Columbia). ${ }^{22}$ For simplicity we now include only dummies for the East and West, with Center as the baseline category. The marginal effects of East and West are both negative and imply a demand for life insurance that is 14.3 or 2.6 percentage points lower than the Center, respectively. At the same time we introduce interaction terms between being an immigrant and the geographic regions where the immigrant resides. This informs us about the life insurance demand by immigrants in the studied regions relative to all Canadian-born respondents. The emerging point estimates are all negative and highly significant. Immigrants living in the Western provinces are the least likely to hold life insurance (16 percentage points less than Canadian-born), followed by the central provinces (11 percentage points), whereas a lower probability of only about 6 percentage points characterises the Eastern provinces. This result highlights the differences between the settlement patterns of immigrants, whereby newly arrived immigrants were more likely to settle in the west. A slow assimilation process may therefore go some way to explain these geographic differences. ${ }^{23}$

In order to enable visual inspection of the results, we construct figures based on Monte Carlo simulation techniques using a specification with the set of controls shown in column (1) of Table $3{ }^{24}$ Figure 1 illustrates how the probability of holding life insurance changes over the lifetime for individuals of various nationalities. This visualises that immigrants in general have lower probabilities of holding life insurance. It also shows that life insurance holding peaks at around age 45 for all nationalities before declining to below $10 \%$ by age 85 . Immigrants from countries such as the USA, Scotland and England display a similar relationship between life insurance and age while for countries such as Russia and China, the relationship is flatter and less hump-shaped.

\section{[Figure 1 about here]}

We next direct our attention to the issue of assimilation and extend the specification by the time that had elapsed since immigration. Following Green and MacKinnon (2001), we set 
the years since immigration variable equal to zero for those born in Canada. The coefficient on this variable can be thus interpreted as the assimilation effect (i.e. no assimilation effect estimated for Canadians). The identification therefore allows the entry effect to vary by place of birth, but imposes a constant assimilation effect (coefficient on years since migration). Column (1) in Table 4 reports the baseline specification extended by the measure of time since immigration. The disclosed point estimate is positive and implies a one percentage point increase in insurance demand for every year that elapsed since immigration to Canada; the effect is however non-linear and occurs at a diminishing rate. We next estimate two linear regressions with the logged value of life insurance and logged income as the dependent variable respectively. This allows us to estimate, in analogy to Green and MacKinnon, years to income equality for immigrants from any nation and then compare it with years to equality in insurance value. Time to assimilation in either of the variables is calculated as the negative ratio between the coefficient estimated for a nationality group divided by the assimilation effect. As can be viewed in column (2), the implied years to equality of life insurance value to a native-born person (entry effect divided by assimilation effect) are fairly substantial. For example, for English-born immigrants time to equality is about 25 years; at the same time, income equality is reached within about 20 years. The fastest assimilation time can be observed for USA-born immigrants who reach equality of insurance value within about nine years. Interestingly, according to our regression, income of immigrants from the US is actually higher than that of Canadians. Comparing the results with Green and MacKinnon's earnings equality, which is reached within roughly seven years, it takes two additional years to reach equality in insurance value. One might expect that assimilation of USA-born would be rapid, since their background matched closely that of the resident population, but this appears not to have been the case. Again, the persistent gap in insurance demand (and not in earnings) may be interpreted as a sign of varying risk attitudes between migrants and non-migrants. The assimilation process is 
also significant for immigrants from other parts of Europe or other parts of the world and lasts typically around 20 years.

\section{[Table 4 about here]}

Figure 2 presents the probability of owning life insurance by immigrants as a function of years that elapsed since their arrival in Canada, while holding all other variables at their mean. It can be observed that immigrants increase their life insurance holdings over a long time period lasting around 45 years after their arrival in Canada. The demand, however, begins to fall for individuals who immigrated more than around five decades ago.

These interpretations must be made, however, under the cautionary note of a limited number of observations for individuals who immigrated a very long time ago. Furthermore, since we have only a cross-section database at our disposal, two important biases arise: cohort effects and survivorship bias. We are not able to illuminate to what extent the concave relationship between insurance holdings and the time that elapsed since immigration is caused by cohort heterogeneity. Such cohort effects could be a result of, for example, some unobservable differences between generations. In addition, it is possible that due to some unobserved reasons, certain types of people have died younger and if their unobserved characteristics are correlated with life insurance holdings, our estimates would be biased. Arguably, the inclusion of a wide set of control variables to some extent mitigates such a bias; nonetheless any interpretation of these results has to be undertaken with care. ${ }^{25}$

\section{[Figure 2 about here]}

A principal aim of this research is to uncover the level of demand for life insurance among migrants relative to non-migrants. The results so far indicate that, on average, immigrants are likely to have a lower level of demand for life insurance. A related question is whether internal migrants are also characterised by a lower insurance demand. Table 5 presents 
results for the sub-sample of Canadian-born household heads. Column (1) contains a dummy variable to identify whether the person has been born in a different province than where he/she is surveyed. The coefficient on this variable is negative, however very close to zero and statistically insignificant. The remaining control variables are very robust for the sub-sample of Canadian-born.

We next exploit geographic information on the origin and destination of the internal migrants and, in analogy to the previous approach, we group provinces into three regions: the East, Center and West. The specification presented in column (2) reports not only the effect of the region of residence, but also the effect of the province of birth. In line with the previous results we find in general a lower insurance demand in the East and West of Canada, compared to the central provinces. The differences in insurance demand depending on region of birth are significant between migrants and non-migrants. The negative marginal effects imply that migrants demand less insurance compared to those who did not migrate and were born in the same region. For example, internal migrants from the Eastern provinces demanded about 26 percentage points less insurance than non-migrants born in the East. Interestingly, migrants also appear to demand more insurance than the residents at the destination.

\section{[Table 5 about here]}

A concern with the potential to undermine our analysis of differences in insurance demand between immigrants and native-born is that of endogeneity. The estimated negative associations between the immigrant dummy and the probability of holding life insurance can be interpreted in two ways. It could be the case that immigrants demanded less insurance because they have lower levels of risk aversion or, alternatively, that insurance companies offer them insurance at higher prices because immigrants were seen as more "risky". If the latter was the case it might be expected that immigrants who did purchase life insurance were charged higher premiums. To explore this, we run two additional regressions, one for immigrants and 
the other for internal migrants, and investigate the existence of any differences in the insurance price paid by immigrants. The results are presented in Table 6 . The model estimates the annual premium paid for life insurance (used as an approximation for insurance price) and uses the previous set of control variables, extended by a measure of the value of life insurance to account for the fact that a more valuable policy is more expensive. The point estimates on the variables identifying immigrants or internal migrants are insignificant implying that being a migrant had no impact on the premium paid. This suggests that differences in insurance purchases were not being driven by higher prices faced by immigrants.

\section{[Table 6 about here]}

\section{Conclusion}

This study investigates the demand for life insurance among household heads in Canada in 1911, placing a particular focus on differences between natives and immigrants. This important time period in Canadian history is characterised by the remarkable growth of both the economy and the population. Moreover, state intervention on the equally rapidly growing insurance market was limited only to regulatory actions. As a result, the decision of a household to purchase insurance at this point in time can be viewed as being based on purely private motivations with the aim of ensuring the best well-being and continued prosperity of their family. Increasing life expectancy meant that the accumulation of assets became more important than ever before while a growing reliance on human capital derived earnings ensured that the income required to obtain these assets became ever more subject to risk. Life insurance could act as an instrument by which to accumulate assets and protect against risk at the same time.

Based on a sample from the Census of Canada we investigate those motivations with a particular focus on immigrants. Holding all else equal, the results indicate that immigrants were 
on average around 13 percentage points less likely to hold life insurance than individuals born in Canada. What is more, the analysis suggests that this was not due to the preferential pricing of insurance contracts in favour of native-born Canadians. Geographic differences are also found to be important, with insurance demand among immigrants differing depending on place of settlement. We also uncover evidence that immigrants took a relatively long time to assimilate in terms of life insurance, longer than it took to assimilate in terms of earnings.

The results for internal migrants are not as strong as those for migrants from abroad. However, the decision to move within the same country is associated with lower risk than moves across borders and as such attitudes towards risk would likely have less of a bearing on the decision to migrate. Furthermore, it important to note that the sample of Canadians is somewhat peculiar, as the vast majority of individuals are themselves a descendent of a migrant (even if not necessarily in the first generation). It is at least a possibility that some of the risk attitudes have persisted over time and it may be difficult to pick up the emerging differences. Finally, this research does not observe migration within a province nor can we account for the duration of a move. It is likely, for example, that short-term internal migration is subject to lower risks than long-term moves, which would have been more typical for immigrants from Europe.

Overall, despite controlling for a wide variety of personal characteristics, differences in insurance supply and geographic variation in insurance holding, the differential between the life insurance demand of immigrants and native-born Canadians remains. As such we tentatively interpret these findings as evidence of differences in attitudes towards risk; that immigrants display relatively lower risk aversion and as a result, demand less insurance. 


\begin{abstract}
${ }^{1}$ Note that informal insurance providers, such as burial societies, were often established by and for members of particular ethnic groups. In section 5, we also provide an analysis of the insurance price paid by immigrants and do not find any significant deviation from the price paid by Canadians.

${ }^{2}$ Missing data on income reduces the number of observations to just below 40,000 in the baseline regressions.
\end{abstract} The main results presented in the paper would remain consistent if we dropped the income measures and worked with the full sample of household heads (not reported).

${ }^{3}$ Those policies might also have been a response to an overall racial animosity of the Canadian population towards Asian immigrants (Ward, 1990).

${ }^{4}$ Nominal values deflated using Wholesale Price Indices from Mitchell (2007).

${ }^{5}$ However, both countries had less extensive life insurance coverage than the United States at this time, as can be seen in Table 1.

${ }^{6}$ Identified when occupation is described as "Insurance agents and brokers" and totalled over the same ethnicity as the individual (as indicated by the racial or tribal origin of individual given in census), divided by population and expressed for each census district per 1,000 citizen.

${ }^{7}$ See footnote 11 for details.

${ }^{8}$ The difference between the proportion of immigrants and Canadians holding life insurance is equal to 5.6 percentage points and is highly statistically significant.

${ }^{9}$ A more fine-grained division of occupation was included in regressions not reported here. The main results of this paper however remain unchanged.

1038 per cent of household heads were classified as "Farmer (owners and tenants)"

${ }^{11}$ As the enumerators were not instructed to differentiate between farmers who owned their own farm and tenant farmers, the limitations of the data prevent an examination of this effect in isolation. See Offer (1991) for a discussion of determinants of farm tenure in England.

12 Household income includes all income from family members and non-family members of the household.

${ }^{13}$ A set of diagnostics has been conducted. First, an OLS regression is implemented using the same dependent and independent variables as the initial Probit model, and the variables are checked for collinearity. Judging on Variance Inflation Factors, no serious problems with collinearity among these variables has been detected. 
Second, a link test is carried out in order to check for a specification error such as omitted variables. The test confirms that meaningful predictors have been chosen, and as the link test is not significant, the model is quite unlikely to be misspecified. Third, a Wald chi-squared test is conducted, and a resulting $p$-value which is significant at the one per cent level indicates that the model has at least some degree of explanatory power. Finally, Hosmer and Lemeshow's goodness-of-fit test indicates that the model fits the data well.

${ }^{14}$ We assume that the decision to migrate would not have been made by the individual if they were below sixteen years of age. This specification also addresses the issue of 'Home Children' immigrants whose passage was subsidised. As many as 80,000 children emigrated from Britain to Canada with the backing of charitable organisations between 1868 and 1924, with approximately 30,000 arriving between 1901 and 1913 (Parr, 1994; Canada Yearbook, 1912 p.46). It is estimated that perhaps $12 \%$ of immigrants living in Canada in 1901 were former Home Children (Green et al., 2002).

${ }^{15}$ An alternative way of measuring age effects would be to include a full set of age dummies to control for life cycle changes. This approach delivers very consistent estimates (not reported).

${ }^{16}$ We have also tried numerous alterations in order to capture the effect of children. Including an indicator function for the presence of children or a full set of dummies for each number of children does not yield any significant children effects, as does controlling for the age of dependent children (not reported).

${ }^{17}$ In an identical regression (not reported) the "official language" variable was separated into those who could speak English and those who could speak French. The results indicate that speaking English was associated with a higher probability of holding life insurance than speaking French.

${ }^{18}$ The only insignificant difference is found between occupations in agriculture and the fisheries and hunting professions, probably the most similar professions. The smallest significant differences are disclosed for the mining, followed by building trades; both professions appear to be particularly risky and may hence attract unusually risk-friendly workers. An alternative way of measuring income is by accounting for the share of family income that the household-head earns. We show in the Appendix Table A1 that the inclusion of a variable measuring the household-head share of household income does not change the results. Since this test leads to a rather large drop in the number of observations, we report this model only as a robustness check.

${ }^{19}$ We have also conducted the analyses separately for sub-samples of farmers and non-farmers. The results remain consistent within each sub-sample (not reported). 
${ }^{20}$ We do not present the differences across provinces in the baseline specification and refer the reader to Appendix Table A2.

${ }^{21}$ Another possible unobserved driver of the results in Di Matteo and Emery (2002) is the origin of the individual, which is not included in their main specification and yet, as observed here, there exist a relatively large differences in religion between Canadians and immigrants (Table 2).

${ }^{22}$ Quebec and Ontario were the two largest provinces in terms of population and also the most urbanised, hence they are grouped together in this context. In the Appendix Table A3 we estimate separate models for the sub-samples of Ontario, Quebec, Eastern or Western provinces (columns 1 to 4). We also conduct further sub-sampling into urban only or rural only respondents (columns 5 and 6). It can be viewed that the lower intake by immigrants is consistent in sign and significance in each of these additional specifications.

${ }^{23}$ For example immigrants to Saskatchewan and Alberta arrived on average around 7-8 years prior to 1911, while immigrants in New Brunswick and Nova Scotia arrived on average 28 and 17 years previously, respectively. The corresponding figures for other provinces are Ontario (25 years), Quebec (16 years), Manitoba (13 years), British Columbia (12 years), New Brunswick (28 years) and Prince Edward Island (43 years).

${ }^{24}$ Using Clarify software (Tomz et al., 2003).

${ }^{25}$ For further relevant discussion see Attanasio and Hoynes (2000).

\section{Acknowledgments}

The authors wish to thank Kevin O'Rourke, Rick Steckel, Ann Carlos, Livio Di Matteo, Cormac Ó Gráda and Janis Umblijs, the editor Nikolaus Wolf and anonymous referees for helpful consultations and insightful comments. 


\section{References}

AMUEDO-DORANTES, C. AND POZO, S. (2002). Precautionary Saving by Young Immigrants and Young Natives, Southern Economic Journal, 69, No. 1, 48-71.

ATTANASIO, O.P. AND HOYNES H.W. (2000). Differential Mortality and Wealth Accumulation, The Journal of Human Resources, 35, No. 1, 1-29.

BISHOP, A.L. (1912). Governmental Regulation of Insurance in Canada, American Political Science Review, 6, No. 2, 175-93.

BOTHWELL, R., DRUMMOND, I. AND ENGLISH, J. (1990). Canada 1990-1945, University of Toronto Press.

BRADLEY, A.G. (1903). Canada in the Twentieth Century, Westminster: Archibald Constable \& Co.

BRAINARD, L. (2008). What is the Role of Insurance in Economic Development? Zurich Government and Industry Affairs thought leadership series, No. 2.

CAMPBELL, R.A. (1980). The Demand for Life Insurance: an Application of the Economics of Uncertainty. Journal of Finance, 35, 155-72.

THE CANADA YEARBOOK (Various Years). Ministry of Trade and Commerce, Ottawa. http://www66.statcan.gc.ca/acyb_000-eng.htm (accessed May 2010). 
CANADIAN CENTURY RESEARCH INFRASTRUCTURE (CCRI) (2009) Census of Population, Canada (1911): CCRI 5 percent sample.

http://ccri.library.ualberta.ca/enindex.html (accessed May 2014).

CARTER, S.B. AND SUTCH, R. (1996). Myth of the Industrial Scrap Heap: A Revisionist View of Turn-of-the-Century American Retirement, Journal of Economic History, 56, No. 1, 5-38.

CENSUS OF CANADA (1911). Library and Archives Canada.

www.collectionscanada.ca/archivianet/1911/index-e.html (accessed May 2010).

CENSUS AND STATISTICS OFFICE (1911). Instructions to Officers, Commissioners and Enumerators: Fifth Census of Canada. Ottawa: Government Printing Bureau. http://ccri.library.ualberta.ca/en1911census/enumeratorinstructions/ (accessed September 2012)

CLEETON, D.L., AND ZELLNER, B.B. (1993). Income, Risk Aversion, and the Demand for Insurance Source, Southern Economic Journal, 60, No. 1, 146-56.

DAVIS, L.E. AND GALLMAN, R.E. (2001). Evolving Financial Markets and International Capital Flows: Britain, the Americas, and Australia, 1865-1914, Cambridge: Cambridge University Press.

DI MATTEO, L. (1996). The Wealth of the Irish in Nineteeth-Century Ontario. Social Science History, 20, No. 2, 209-34. 
DI MATTEO, L. (1997). The determinants of wealth and asset holding in nineteenth century Canada: evidence from micro-data. Journal of Economic History, 57, 907-34.

DI MATTEO L. AND EMERY J.C.H. (2002). Wealth and the demand for life insurance: Evidence from Ontario, 1892, Explorations in Economic History, 39, No. 4, 446-69.

DRUMMOND, I.M. (1962). Canadian Life Insurance Companies and the Capital Market, 1890-1914, Canadian Journal of Economics and Political Science / Revue canadienne d'Economique et de Science politique, 28, No. 2, 204-24.

DUKER, J.M. (1969). Expenditures for life insurance among working-wife families, Journal of Risk and Insurance, 36, 525-33.

FLANDREAU, M. AND ZUMER, F. (2004). The Making of Global Finance 1880-1913, OECD Development Centre.

GREEN, A.G., MACKINNON M. (2001). The Slow Assimilation of British Immigrants in Canada: Evidence from Montreal and Toronto, 1901, Explorations in Economic History, 38, No. 3, 315-338.

GREEN, A.G., MACKINNON M. AND MINNS C. (2002). Dominion or Republic? Migrants to North America from the United Kingdom, 1870-1910, Economic History Review, 40, No. 4, 666-96. 
HAMMOND, J.D., HOUSTON, D.B. AND MELANDER, E.R. (1967). Determinants of Household Life Insurance Premium Expenditures: An Empirical Investigation Source, Journal of Risk and Insurance, 34, No. 3, 397-408.

HATTON, T.J. (1997). The Immigrant Assimilation Puzzle in Late Nineteenth-Century America, The Journal of Economic History, 57, No. 1, 34-62.

IAIABC (2010). International Association of Industrial Accident Boards and Commissions, http://www.iaiabc.org/i4a/pages/index.cfm?pageid=3299 (accessed May 2010).

THE INSURANCE MONITOR (1919). (July, Vol. 67, No. 7).

JAEGER, D. A., DOHMEN, T., FALK, A., HUFFMAN, D., SUNDE, U., \& BONIN, H. (2010). Direct evidence on risk attitudes and migration. The Review of Economics and Statistics, 92, No.3, 684-689.

JAPPELLI, T, AND MODIGLIANI, F. (2006). The age-saving profile and the life-cycle hypothesis in Klein, L.R. (ed.), Long Run Growth And Short Run Stabilization: Essays in Memory of Albert Ando, Edward Elgar Publishing.

KANTOR, S.E. AND FISHBACK, P.V. (1996). Precautionary Saving, Insurance, and the Origins of Workers Compensation. Journal of Political Economy, 104, 419-42.

KELLER, M. (1999). The Life Insurance Enterprise, 1885-1910: A Study in the Limits of Corporate Power, Belnap Press. 
LEWIS, F. D. (1989). Dependents and the demand for life insurance. American Economic Review, 79, 452-67.

LIEBENBERG, A.P., CARSON, J.M. AND DUMM, R.E. (2012). A Dynamic Analysis of the Demand for Life Insurance, Journal of Risk and Insurance, 79, No.3, 619-644.

THE MADDISON PROJECT (2013).

http://www.ggdc.net/maddison/maddison-project/home.htm, 2013 version.

MCINNIS, M. (2008). Canadian Economic Development in the Wheat Boom Era: A Reassessment, Working Paper, Queen’s University, Ontario, Canada.

MEREDITH, W.R. (1913). The Meredith Report, Legislative Assembly of Ontario, Toronto, Ontario.

MITCHELL, B.R. (2007). International Historical Statistics: The Americas 1750-2005, $6^{\text {th }}$ ed. Basingstoke: Palgrave MacMillan.

NEW YORK TIMES (1912). Canada's High Mark in Foreign Trade, New York Times, $22^{\text {nd }}$ June 1912.

OFFER, A. (1991). Farm tenure and land values in England, c. 1750-1950, Economic History Review, 44, No. 1, 1-20. 
PARR, J. (1994). Labouring Children: British Immigrant Apprentices to Canada, 1869-1924, University of Toronto Press.

POWELL, J. (2005). A History of the Canadian Dollar, Bank of Canada, http://www.bankofcanada.ca/wp-content/uploads/2010/07/dollar_book.pdf

REGEHR, T.D. (2011). Dominion Lands Policy, The Canadian Encyclopedia. Historica Foundation, http://www.thecanadianencyclopedia.com (accessed September 2011).

ROSENZWEIG, M. R. (2001). Savings Behaviour in Low-Income Countries, Oxford Review of Economic Policy, 17, No. 1, 40-54.

SCOBIE, C.H.H. AND RAWLYK, G., (1997). The Contribution of Presbyterianism to the Maritime Provinces of Canada, McGill-Queen’s University Press.

SHEPPARD, D.K. (2013). The Growth and Role of UK Financial Institutions, 1880-1966, Routledge.

SOLBERG, C.E. (1987). The Prairies and the Pampas: Agrarian Policy in Canada and Argentina, 1880-1930, Stanford University Press.

SPECTATOR COMPANY (1916). Practical pointers; various phases of field work discussed in a manner designed to afford aid and suggestion to the man with the rate book, Chicago: The Spectator Company. 
STEAD, D.R. (2004). Risk and risk management in English agriculture, c. 1750-1850, Economic History review, 57, No.2, 334-61.

THOMASSON, M. (2003). Health Insurance in the United States, EH.Net Encyclopedia, edited by Robert Whaples. http://eh.net/encyclopedia/article/thomasson.insurance.health.us (accessed September 2011).

TOMZ, M, WITTENBERG, J. AND KING, G. (2003). CLARIFY: Software for Interpreting and Presenting Statistical Results. Journal of Statistical Software.

TRUETT, D.B. AND TRUETT, L.J. (1990). The Demand for Life Insurance in Mexico and the United States: A Comparative Study, Journal of Risk and Insurance, 57, No. 2, 321-28.

UNITED STATES BUREAU OF THE CENSUS (1976), The Statistical History of the United States, from Colonial Times to the Present, Basic Books.

WARD, P. (1990). White Canada Forever: Popular Attitudes and Public Policy Toward Orientals in British Columbia, $3^{\text {rd }}$ ed. McGill-Queen's Press. 


\section{Tables and Figures}

Table 1. Life Insurance Premium Income per capita (US\$), 1911.

\begin{tabular}{lccc}
\hline & Canada & US & UK \\
\cline { 2 - 4 } Total Life Premium Income & $31,619,626$ & $625,900,000$ & $223,663,500$ \\
Population & $7,206,643$ & $93,863,000$ & $44,916,000$ \\
GDP per capita (1990 Int. GK\$) & 4,213 & 5,406 & 4,709 \\
Premium Income per capita & 4.39 & 6.67 & 4.98 \\
\hline \hline
\end{tabular}

Sources: Canada Yearbook (1912), United States Bureau of the Census (1976), Sheppard (2013), Flandreau and Zumer (2004), Powell (2005), Maddison (2013).

Table 2. Descriptive Statistics. 5\% Sample, Household-heads only.

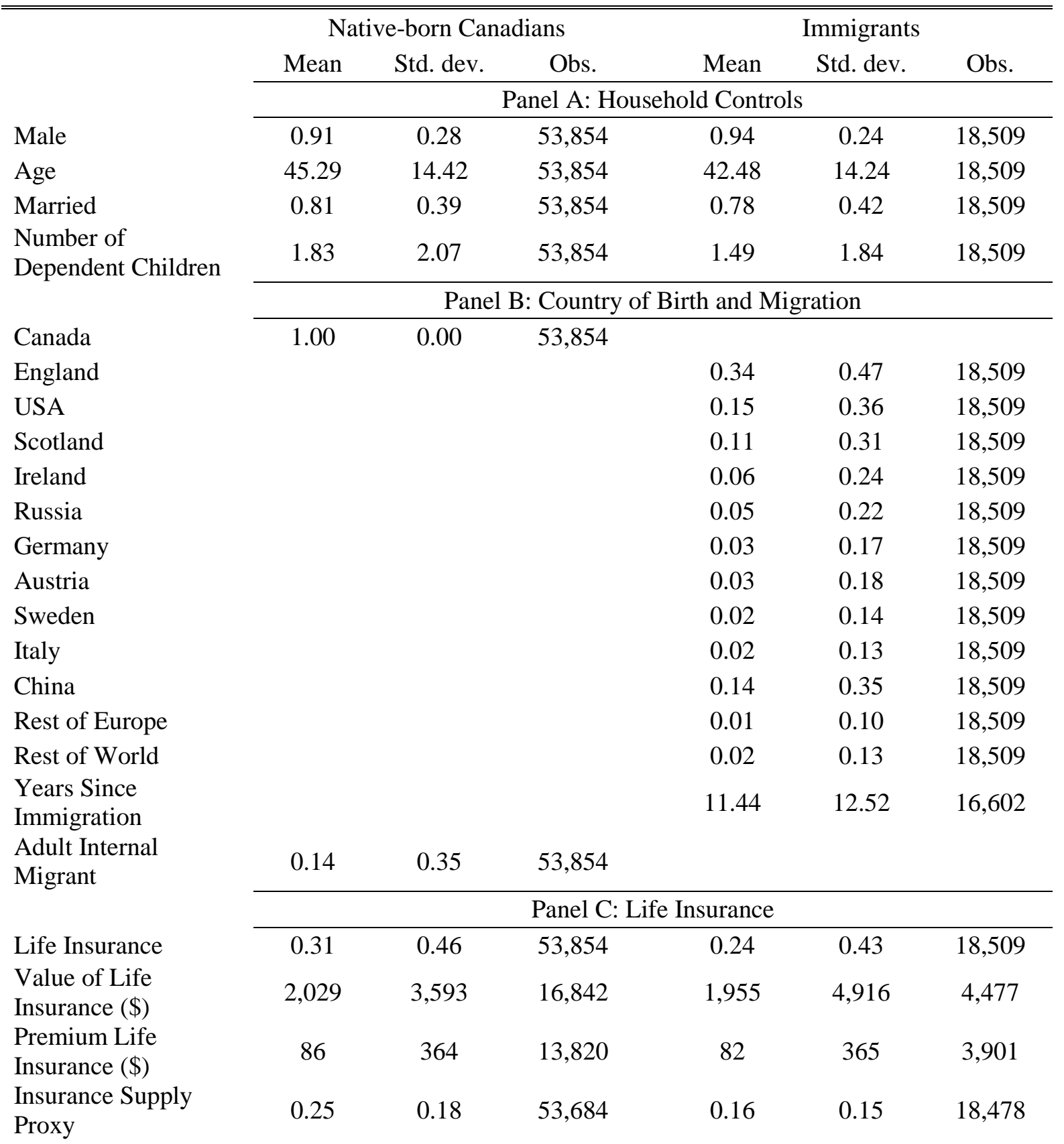




\begin{tabular}{|c|c|c|c|c|c|c|}
\hline & & & & & & \\
\hline Occ 0 - Agriculture & 0.45 & 0.50 & 47,609 & 0.40 & 0.49 & 16,605 \\
\hline $\begin{array}{l}\text { Occ } 1 \text { - Building } \\
\text { trades }\end{array}$ & 0.09 & 0.29 & 47,609 & 0.40 & 0.49 & 16,605 \\
\hline $\begin{array}{l}\text { Occ } 2 \text { - Domestic and } \\
\text { personal service }\end{array}$ & 0.03 & 0.18 & 47,609 & 0.10 & 0.30 & 16,605 \\
\hline $\begin{array}{l}\text { Occ } 3 \text { - Civil and } \\
\text { municipal service }\end{array}$ & 0.03 & 0.18 & 47,609 & 0.04 & 0.19 & 16,605 \\
\hline $\begin{array}{l}\text { Occ } 4 \text { - Fisheries and } \\
\text { hunting }\end{array}$ & 0.02 & 0.13 & 47,609 & 0.04 & 0.20 & 16,605 \\
\hline $\begin{array}{l}\text { Occ } 5 \text { - Forestry and } \\
\text { lumbering }\end{array}$ & 0.04 & 0.20 & 47,609 & 0.01 & 0.09 & 16,605 \\
\hline $\begin{array}{l}\text { Occ } 6 \text { - Manufactures } \\
\text { (mechanical) }\end{array}$ & 0.06 & 0.23 & 47,609 & 0.03 & 0.16 & 16,605 \\
\hline $\begin{array}{l}\text { Occ } 7 \text { - Manufactures } \\
\text { (Food \& clothing) }\end{array}$ & 0.05 & 0.21 & 47,609 & 0.07 & 0.26 & 16,605 \\
\hline Occ 8 - Mining & 0.02 & 0.13 & 47,609 & 0.05 & 0.22 & 16,605 \\
\hline $\begin{array}{l}\text { Occ } 9 \text { - Professional } \\
\text { pursuits }\end{array}$ & 0.03 & 0.16 & 47,609 & 0.04 & 0.19 & 16,605 \\
\hline $\begin{array}{l}\text { Occ } 10 \text { - Trade and } \\
\text { Merchandising }\end{array}$ & 0.11 & 0.31 & 47,609 & 0.03 & 0.17 & 16,605 \\
\hline $\begin{array}{l}\text { Occ } 11 \text { - } \\
\text { Transportation }\end{array}$ & 0.08 & 0.27 & 47,609 & 0.11 & 0.31 & 16,605 \\
\hline $\begin{array}{l}\text { Self-Employed- } \\
\text { Farmer-Employer }\end{array}$ & 0.37 & 0.48 & 53,854 & 0.32 & 0.47 & 18,509 \\
\hline $\begin{array}{l}\text { Income of Household } \\
\text { Head (last year) (\$) }\end{array}$ & 735 & 903 & 23,016 & 772 & 983 & 8,654 \\
\hline $\begin{array}{l}\text { Total Income of } \\
\text { Household (last year) } \\
\text { (\$) }\end{array}$ & 981 & 1425 & 31,103 & 1410 & 2135 & 10,816 \\
\hline Second Income & 0.21 & 0.41 & 53,854 & 0.26 & 0.44 & 18,509 \\
\hline $\begin{array}{l}\text { Household-head } \\
\text { share of Household } \\
\text { Income (last year) (\$) }\end{array}$ & 0.82 & 0.27 & 23,013 & 0.76 & 0.32 & 8,650 \\
\hline & & & nel E: Lit & Langl & & \\
\hline Read and Write & 0.89 & 0.31 & 50,541 & 0.92 & 0.27 & 18,509 \\
\hline Speaks English & 0.76 & 0.43 & 53,854 & 0.86 & 0.34 & 18,509 \\
\hline Speaks French & 0.32 & 0.46 & 53,854 & 0.05 & 0.21 & 18,509 \\
\hline & & & Panel & gion & & \\
\hline Catholic & 0.41 & 0.49 & 53,854 & 0.19 & 0.39 & 18,509 \\
\hline Anglican & 0.11 & 0.31 & 53,854 & 0.25 & 0.43 & 18,509 \\
\hline Methodist & 0.18 & 0.39 & 53,854 & 0.12 & 0.32 & 18,509 \\
\hline Baptist & 0.06 & 0.24 & 53,854 & 0.04 & 0.19 & 18,509 \\
\hline Presbyterian & 0.17 & 0.38 & 53,854 & 0.16 & 0.37 & 18,509 \\
\hline Protestant & 0.00 & 0.05 & 53,854 & 0.01 & 0.11 & 18,509 \\
\hline Lutheran & 0.01 & 0.11 & 53,854 & 0.09 & 0.29 & 18,509 \\
\hline Jewish & 0.00 & 0.04 & 53,854 & 0.03 & 0.18 & 18,509 \\
\hline Other Religion & 0.04 & 0.21 & 53,854 & 0.11 & 0.31 & 18,509 \\
\hline & & & Panel C & raphy & & \\
\hline Urban & 0.43 & 0.50 & 53,854 & 0.52 & 0.50 & 18,509 \\
\hline
\end{tabular}




\begin{tabular}{lllllll} 
Alberta & 0.03 & 0.17 & 53,854 & 0.15 & 0.36 & 18,509 \\
British Columbia & 0.03 & 0.17 & 53,854 & 0.14 & 0.34 & 18,509 \\
Manitoba & 0.04 & 0.20 & 53,854 & 0.13 & 0.33 & 18,509 \\
New Brunswick & 0.06 & 0.23 & 53,854 & 0.01 & 0.11 & 18,509 \\
Nova Scotia & 0.08 & 0.27 & 53,854 & 0.02 & 0.15 & 18,509 \\
Ontario & 0.39 & 0.49 & 53,854 & 0.30 & 0.46 & 18,509 \\
Prince Edward Island & 0.02 & 0.13 & 53,854 & 0.00 & 0.04 & 18,509 \\
Quebec & 0.30 & 0.46 & 53,854 & 0.09 & 0.29 & 18,509 \\
Saskatchewan & 0.04 & 0.21 & 53,854 & 0.17 & 0.37 & 18,509 \\
\hline \hline
\end{tabular}

Source: 5\% Sample of Census of Canada, 1911, CCRI.

Note: Sample sizes differ due to missing data for particular variables (e.g. insurance premiums) 
Table 3. The Demand for Life Insurance and Immigration.

\begin{tabular}{cccc}
\multicolumn{5}{c}{ Life Insurance } \\
\hline \multicolumn{4}{c}{ Probit } \\
(1) & (2) & (3) & (4) \\
\hline
\end{tabular}

Immigrant

USA

England

Ireland

Scotland

Germany

Italy

Russia

Sweden

Austria

Rest of Europe

China

Rest of World

Male

Married

Age

Age $^{2}$

Dependent children

Literate

Speaks official

language

Urban agglomeration

\begin{abstract}
$-0.128 * * *$
(0.00616)
\end{abstract}

$-0.111^{* * *}$

(0.00651)

$-0.0648^{* * *}$

(0.0136)

$-0.0823 * * *$

(0.00793)

$-0.0630 * * *$

(0.0172)

$-0.0346^{* *}$

(0.0137)

$-0.126^{* * *}$

(0.0256)

$-0.312 * * *$

(0.0130)

$-0.288 * * *$

(0.0120)

$-0.170 * * *$

(0.0320)

$-0.304 * * *$

(0.0145)

$-0.174 * * *$

(0.0119)

$-0.335^{* * *}$

(0.0181)

$-0.181^{* * *}$

(0.0274)

$0.214 * * * \quad 0.219 * * *$

$0.216^{* * *}$

$0.209 * * *$

(0.0136)

(0.0131)

(0.0134)

(0.0138)

$0.128^{* * *} \quad 0.123^{* * *} \quad 0.126^{* * *} \quad 0.133^{* * *}$

$(0.00852)$

(0.00858)

(0.00854)

(0.00843)

$0.0206^{* * *}$

$0.0198 * * *$

$0.0214^{* * * *}$

(0.00146)

$(0.00145)$

$0.0199 * * *$

$(0.00146)$

$\begin{array}{llll}-0.00025^{* * *} & -0.00023^{* * *} & -0.00024^{* * *} & -0.00025 * * *\end{array}$

(1.62e-05)

(1.61e-05)

(1.61e-05)

(1.61e-05)

$-0.000435$

0.000878

0.00154

$-0.00206$

(0.00146)

(0.00147)

(0.00148)

(0.00145)

$0.183^{* * *}$

$0.173^{* * *}$

$0.175^{* * *}$

$0.195^{* * *}$

(0.00847)

(0.00869)

(0.00871)

(0.00815)

$0.139 * * *$

$0.0984 * * *$

$0.112^{* * *}$

$0.128^{* * *}$

(0.0112)

(0.0124)

(0.0121)

(0.0115)

$0.113^{* * *}$

$0.115^{* * *}$

$0.115^{* * *}$

$0.114^{* * *}$ 


\begin{tabular}{|c|c|c|c|c|}
\hline & $(0.00688)$ & $(0.00687)$ & $(0.00688)$ & $(0.00681)$ \\
\hline Household income & $\begin{array}{l}0.0287 * * * \\
(0.00532)\end{array}$ & $\begin{array}{c}0.0305^{* * *} \\
(0.00530)\end{array}$ & $\begin{array}{c}0.0281^{* * *} \\
(0.00549)\end{array}$ & $\begin{array}{c}0.0275^{* * *} \\
(0.00519)\end{array}$ \\
\hline (Household income) $^{2}$ & $\begin{array}{c}-0.00105^{* * *} \\
(0.000406)\end{array}$ & $\begin{array}{c}-0.00111^{* * *} \\
(0.000403)\end{array}$ & $\begin{array}{c}-0.000993^{* *} \\
(0.000417)\end{array}$ & $\begin{array}{c}-0.00104 * * * \\
(0.000394)\end{array}$ \\
\hline Farmer & $\begin{array}{c}0.0140 \\
(0.0145)\end{array}$ & $\begin{array}{c}0.0186 \\
(0.0145)\end{array}$ & $\begin{array}{c}0.0142 \\
(0.0145)\end{array}$ & $\begin{array}{c}0.0113 \\
(0.0145)\end{array}$ \\
\hline Insurance supply & $\begin{array}{c}0.132 * * * \\
(0.0180)\end{array}$ & $\begin{array}{c}0.0710^{* * *} \\
(0.0191)\end{array}$ & $\begin{array}{c}0.111^{* * *} \\
(0.0188)\end{array}$ & $\begin{array}{c}0.0573^{* * *} \\
(0.0170)\end{array}$ \\
\hline Anglican & & & $\begin{array}{c}0.00902 \\
(0.00921)\end{array}$ & \\
\hline Methodist & & & $\begin{array}{c}0.0705^{* * *} \\
(0.00966)\end{array}$ & \\
\hline Baptist & & & $\begin{array}{c}0.0385^{* * *} \\
(0.0132)\end{array}$ & \\
\hline Presbyterian & & & $\begin{array}{c}0.0710^{* * *} \\
(0.00951)\end{array}$ & \\
\hline Protestant & & & $\begin{array}{c}0.0192 \\
(0.0396)\end{array}$ & \\
\hline Lutheran & & & $\begin{array}{c}-0.0479 * * * \\
(0.0186)\end{array}$ & \\
\hline Jewish & & & $\begin{array}{c}-0.204^{* * *} \\
(0.0185)\end{array}$ & \\
\hline other & & & $\begin{array}{l}-0.0165 \\
(0.0134)\end{array}$ & \\
\hline Immigrant * East & & & & $\begin{array}{c}-0.0577 * * \\
(0.0256)\end{array}$ \\
\hline Immigrant * Center & & & & $\begin{array}{l}-0.107 * * * \\
(0.00741)\end{array}$ \\
\hline Immigrant * West & & & & $\begin{array}{l}-0.162 * * * \\
(0.00987)\end{array}$ \\
\hline East & & & & $\begin{array}{l}-0.143 * * * \\
(0.00813)\end{array}$ \\
\hline West & & & & $\begin{array}{c}-0.0256^{* *} \\
(0.0100)\end{array}$ \\
\hline Province controls & yes & yes & yes & \\
\hline Occupation controls & yes & yes & yes & yes \\
\hline Observations & 37,977 & 37,977 & 37,977 & 37,977 \\
\hline Pseudo- $\mathrm{R}^{2}$ & 0.126 & 0.133 & 0.131 & 0.122 \\
\hline
\end{tabular}

Note: Robust standard errors in parentheses. Omitted categories - Country (column 2): Canada, Religion: Roman Catholic, Region: Center. *** $\mathrm{p}<0.01,{ }^{* *} \mathrm{p}<0.05,{ }^{*} \mathrm{p}<0.1$. 
Table 4. Life Insurance Demand and Assimilation.

\begin{tabular}{|c|c|c|c|}
\hline & Life Insurance & $\begin{array}{c}\ln (\text { Value of } \\
\text { Life } \\
\text { Insurance) }\end{array}$ & $\ln ($ Income $)$ \\
\hline & $\begin{array}{c}\text { Probit } \\
(1) \\
\end{array}$ & $\begin{array}{c}\text { OLS } \\
(2) \\
\end{array}$ & $\begin{array}{c}\text { OLS } \\
(3) \\
\end{array}$ \\
\hline $\begin{array}{l}\text { Years since } \\
\text { immigration }\end{array}$ & $\begin{array}{c}0.0106^{* * * *} \\
(0.00104)\end{array}$ & $\begin{array}{c}0.0448 * * * \\
(0.00367)\end{array}$ & $\begin{array}{c}0.0110^{* * *} \\
(0.00157)\end{array}$ \\
\hline $\begin{array}{l}\text { (Years since }^{2} \\
\text { immigration) }^{2}\end{array}$ & $\begin{array}{c}-0.000107^{* * *} \\
(2.01 \mathrm{e}-05)\end{array}$ & $\begin{array}{c}-0.00048 * * * \\
(7.15 \mathrm{e}-05)\end{array}$ & $\begin{array}{c}-0.00013^{* * *} \\
(3.30 \mathrm{e}-05)\end{array}$ \\
\hline USA & $\begin{array}{c}-0.158^{* * *} \\
(0.0135)\end{array}$ & $\begin{array}{c}-0.392^{* * *} \\
(0.0583)\end{array}$ & $\begin{array}{c}0.0215 \\
(0.0272)\end{array}$ \\
\hline England & $\begin{array}{l}-0.181 * * * \\
(0.00953)\end{array}$ & $\begin{array}{c}-1.117^{* * *} \\
(0.0447)\end{array}$ & $\begin{array}{c}-0.215^{* * *} \\
(0.0155)\end{array}$ \\
\hline Ireland & $\begin{array}{c}-0.196 * * * \\
(0.0151)\end{array}$ & $\begin{array}{c}-0.974 * * * \\
(0.0758)\end{array}$ & $\begin{array}{c}-0.256 * * * \\
(0.0307)\end{array}$ \\
\hline Scotland & $\begin{array}{c}-0.135^{* * *} \\
(0.0138)\end{array}$ & $\begin{array}{c}-0.874 * * * \\
(0.0531)\end{array}$ & $\begin{array}{c}-0.116^{* * *} \\
(0.0205)\end{array}$ \\
\hline Germany & $\begin{array}{c}-0.233^{* * *} \\
(0.0190)\end{array}$ & $\begin{array}{c}-0.717^{* * *} \\
(0.110)\end{array}$ & $\begin{array}{c}-0.249 * * * \\
(0.0466)\end{array}$ \\
\hline Italy & $\begin{array}{l}-0.335^{* * *} \\
(0.00836)\end{array}$ & $\begin{array}{c}-1.129 * * * \\
(0.188)\end{array}$ & $\begin{array}{c}-0.251 * * * \\
(0.0364)\end{array}$ \\
\hline Russia & $\begin{array}{l}-0.319 * * * \\
(0.00852)\end{array}$ & $\begin{array}{c}-0.808^{* * *} \\
(0.118)\end{array}$ & $\begin{array}{c}-0.203^{* * *} \\
(0.0323)\end{array}$ \\
\hline Sweden & $\begin{array}{c}-0.240 * * * \\
(0.0247)\end{array}$ & $\begin{array}{c}-0.968 * * * \\
(0.153)\end{array}$ & $\begin{array}{l}-0.0401 \\
(0.0575)\end{array}$ \\
\hline Austria & $\begin{array}{c}-0.327^{* * *} \\
(0.0101)\end{array}$ & $\begin{array}{c}-0.602 * * * \\
(0.134)\end{array}$ & $\begin{array}{c}-0.289 * * * \\
(0.0397)\end{array}$ \\
\hline Rest of Europe & $\begin{array}{c}-0.263^{* * *} \\
(0.00993)\end{array}$ & $\begin{array}{c}-0.916 * * * \\
(0.0690)\end{array}$ & $\begin{array}{c}-0.206 * * * \\
(0.0243)\end{array}$ \\
\hline China & $\begin{array}{c}-0.350 * * * \\
(0.00947)\end{array}$ & $\begin{array}{c}-1.509 * * * \\
(0.0698)\end{array}$ & $\begin{array}{c}-0.466 * * * \\
(0.0767)\end{array}$ \\
\hline Rest of World & $\begin{array}{c}-0.252^{* * *} \\
(0.0214)\end{array}$ & $\begin{array}{c}-0.851 * * * \\
(0.136)\end{array}$ & $\begin{array}{c}-0.322 * * * \\
(0.0492)\end{array}$ \\
\hline Male & $\begin{array}{c}0.224^{* * * *} \\
(0.0130)\end{array}$ & $\begin{array}{c}1.005^{* * * *} \\
(0.106)\end{array}$ & $\begin{array}{c}0.581^{* * * *} \\
(0.0340)\end{array}$ \\
\hline Married & $\begin{array}{l}0.124 * * * \\
(0.00873)\end{array}$ & $\begin{array}{c}0.0301 \\
(0.0330)\end{array}$ & $\begin{array}{c}0.108 * * * \\
(0.0150)\end{array}$ \\
\hline Age & $\begin{array}{c}0.0197 * * * \\
(0.00152)\end{array}$ & $\begin{array}{c}0.0328 * * * \\
(0.00513)\end{array}$ & $\begin{array}{c}0.0304 * * * \\
(0.00212)\end{array}$ \\
\hline $\mathrm{Age}^{2}$ & $\begin{array}{c}-0.000247^{* * *} \\
(1.69 \mathrm{e}-05)\end{array}$ & $\begin{array}{c}-0.00036 * * * \\
(5.95 \mathrm{e}-05)\end{array}$ & $\begin{array}{c}-0.00037^{* * *} \\
(2.44 \mathrm{e}-05)\end{array}$ \\
\hline Dependent children & $\begin{array}{l}0.000316 \\
(0.00149)\end{array}$ & $\begin{array}{c}-0.0129 * * * \\
(0.00446)\end{array}$ & $\begin{array}{l}-0.00288 \\
(0.00215)\end{array}$ \\
\hline Literate & $0.173 * * *$ & $0.460 * * *$ & $0.252 * * *$ \\
\hline
\end{tabular}




\begin{tabular}{lccc} 
& $(0.00876)$ & $(0.0467)$ & $(0.0141)$ \\
Speaks official & $0.0935^{* * *}$ & 0.0771 & $0.174^{* * *}$ \\
language & $(0.0127)$ & $(0.0512)$ & $(0.0190)$ \\
Urban agglomeration & $0.114^{* * *}$ & 0.0183 & $0.274^{* * *}$ \\
& $(0.00695)$ & $(0.0221)$ & $(0.00983)$ \\
Household income & $0.0306^{* * *}$ & $0.127^{* * *}$ & \\
& $(0.00519)$ & $(0.0128)$ & \\
(Household income) & $-0.00111^{* * *}$ & $-0.00204^{* *}$ & \\
Farmer & $(0.000394)$ & $(0.000946)$ & \\
& 0.0171 & $0.0904^{*}$ & -0.0212 \\
Insurance supply & $(0.0146)$ & $(0.0473)$ & $(0.0245)$ \\
& $0.0617^{* * *}$ & $-0.176^{* * *}$ & \\
Second income & $(0.0195)$ & $(0.0591)$ & \\
& & & $0.0418^{* * *}$ \\
Province controls & & & $(0.00819)$ \\
Occupation controls & yes & yes & yes \\
Observations & yes & yes & yes \\
$\mathrm{R}^{2}$ & 36,911 & 14,313 & 29,932 \\
\hline \hline
\end{tabular}

Note: Robust standard errors in parentheses. Column (1) reports the pseudo-R2 coefficient. Columns (2) and (3) include a constant (not reported). Omitted categories - Country: Canada ${ }^{* * *} \mathrm{p}<0.01$, ${ }^{* *} \mathrm{p}<0.05$, $* \mathrm{p}<0.1$. 
Table 5. The Demand for Life Insurance and Internal Migration.

\begin{tabular}{|c|c|c|}
\hline & $\begin{array}{c}\text { Life } \\
\text { Insurance } \\
\text { Probit } \\
(1)\end{array}$ & $\begin{array}{c}\text { Life } \\
\text { Insurance } \\
\text { Probit } \\
(2) \\
\end{array}$ \\
\hline Internal migrant & $\begin{array}{c}-0.00884 \\
(0.0158)\end{array}$ & \\
\hline (Internal migrant) $*$ (Born in East) & & $\begin{array}{c}-0.261 * * * \\
(0.0919)\end{array}$ \\
\hline (Internal migrant) $*($ Born in Center $)$ & & $\begin{array}{c}-0.114 * * \\
(0.0572)\end{array}$ \\
\hline (Internal migrant) * (Born in West) & & $\begin{array}{c}-0.170 * * \\
(0.0839)\end{array}$ \\
\hline (Internal migrant) $*$ East & & $\begin{array}{c}0.302 * * \\
(0.154)\end{array}$ \\
\hline (Internal migrant) $*$ Center & & $\begin{array}{c}0.118 * \\
(0.0682)\end{array}$ \\
\hline (Internal migrant) $*$ West & & $\begin{array}{c}0.263 * * * \\
(0.0922)\end{array}$ \\
\hline East & & $\begin{array}{c}-0.274^{* *} \\
(0.106)\end{array}$ \\
\hline West & & $\begin{array}{c}-0.147 * * \\
(0.0582)\end{array}$ \\
\hline Male & $\begin{array}{c}0.254 * * * \\
(0.0148)\end{array}$ & $\begin{array}{c}0.251^{* * *} \\
(0.0150)\end{array}$ \\
\hline Married & $\begin{array}{c}0.124^{* * *} \\
(0.0109)\end{array}$ & $\begin{array}{c}0.127 * * * \\
(0.0108)\end{array}$ \\
\hline Age & $\begin{array}{c}0.0201^{* * *} \\
(0.00184) \\
-\end{array}$ & $\begin{array}{c}0.0209 * * * \\
(0.00184) \\
-\end{array}$ \\
\hline Age $^{2}$ & $\begin{array}{c}0.000256^{* * *} \\
(2.05 \mathrm{e}-05)\end{array}$ & $\begin{array}{c}0.000264 * * * \\
(2.05 \mathrm{e}-05)\end{array}$ \\
\hline Dependent children & $\begin{array}{l}-0.000196 \\
(0.00174)\end{array}$ & $\begin{array}{l}-0.00206 \\
(0.00171)\end{array}$ \\
\hline Literate & $\begin{array}{c}0.175^{* * *} \\
(0.0101)\end{array}$ & $\begin{array}{l}0.187 * * * \\
(0.00974)\end{array}$ \\
\hline Speaks official language & $\begin{array}{c}0.0208 \\
(0.0172)\end{array}$ & $\begin{array}{c}0.000462 \\
(0.0174)\end{array}$ \\
\hline Urban agglomeration & $\begin{array}{l}0.128 * * * \\
(0.00816)\end{array}$ & $\begin{array}{l}0.129 * * * \\
(0.00812)\end{array}$ \\
\hline Household income & $\begin{array}{c}0.0571^{* * *} \\
(0.00558)\end{array}$ & $\begin{array}{c}0.0564 * * * \\
(0.00563)\end{array}$ \\
\hline (Household income) $^{2}$ & $\begin{array}{c}-0.00345^{* * *} \\
(0.000541)\end{array}$ & $\begin{array}{c}-0.00342^{* * *} \\
(0.000550)\end{array}$ \\
\hline Farmer & $0.0399 * *$ & $0.0385^{* *}$ \\
\hline
\end{tabular}


Insurance supply

$\begin{array}{cc}(0.0172) & (0.0172) \\ 0.000132 & 0.000265 \\ (0.000937) & (0.000923)\end{array}$

Province controls

yes

Birth province controls

yes

Occupation controls

yes

yes

Observations $\quad 26,415 \quad 26,497$

$\mathrm{R}^{2} \quad 0.143 \quad 0.139$

Note: Robust standard errors in parentheses. Omitted categories -

Region: Center.

${ }^{* * *} \mathrm{p}<0.01,{ }^{* *} \mathrm{p}<0.05,{ }^{*} \mathrm{p}<0.1$. 
Table 6. The Demand for Life Insurance and Internal Migration.

\begin{tabular}{lcc}
\hline \hline & \multicolumn{2}{c}{$\ln$ OLS } \\
\cline { 2 - 3 } & $(1)$ & $(2)$ \\
\cline { 2 - 3 } & & \\
Immigrant & 0.0105 & \\
& $(0.0396)$ & 0.0471 \\
Internal migrant & & $(0.0466)$ \\
& & $0.591^{* * *}$ \\
In(Value of Life & & $(0.0256)$
\end{tabular}

Individual and household

controls

yes

yes

Province controls

yes

yes

Occupation controls

yes

yes

Insurance supply controls

yes

yes

Country of birth controls

yes

Province of birth controls

yes

Observations

11,985

8,643

$\mathrm{R}^{2}$

0.365

0.348

\footnotetext{
Note: Robust standard errors in parentheses. The regressions

include a complete set of control variables, that is individual and household level controls (gender, civil status, quadratic age polynomial, number of dependent children, literacy, official
} 
language, urban agglomeration, quadratic household income polynomial, farmer), province of residence, occupation and insurance supply controls. The specification in column (1) contains in addition country of birth controls, whereas column (2) includes province of birth controls (not reported). ${ }^{* * *} \mathrm{p}<0.01$, ** $\mathrm{p}<0.05, * \mathrm{p}<0.1$.

Omitted categories - Religion: Roman Catholic, Region: Center, Country: Canada. 
Figure 1. Probability of having life insurance and age (by country of origin).

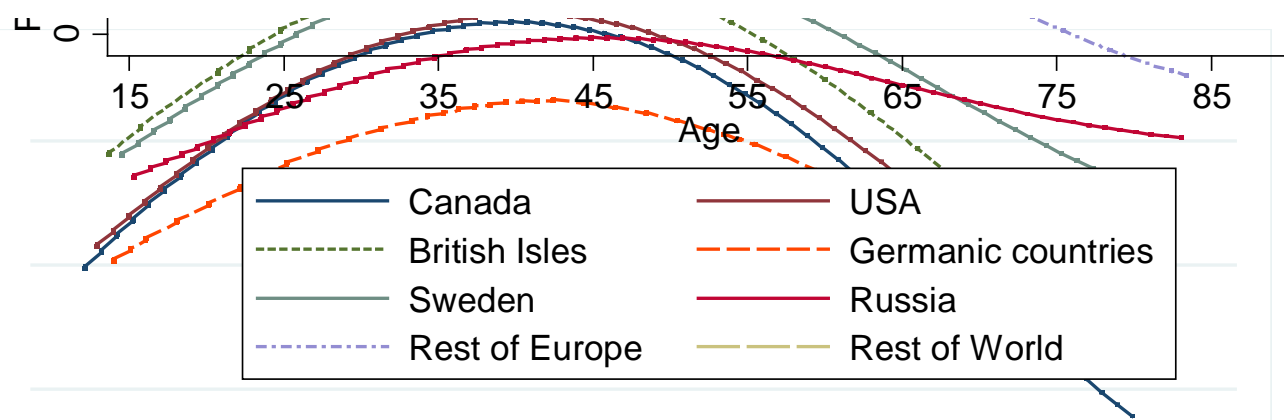

Note: Probabilities of having life insurance are obtained by the means of Monte Carlo simulation techniques and based on the model outlined in column (2) of Table 3.

Figure 2. Probability of having life insurance and years since immigration. 


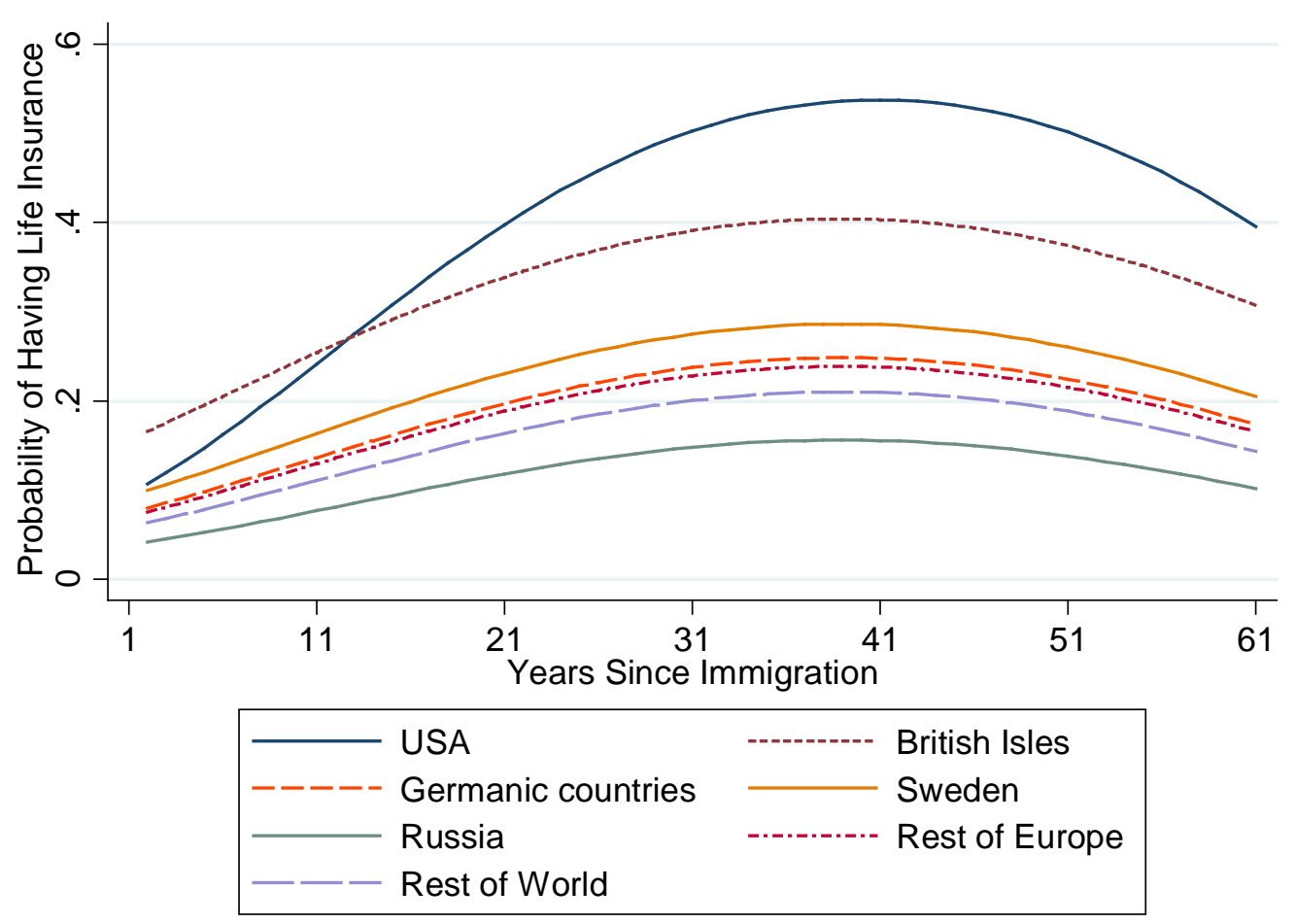

Note: Probabilities of having life insurance are obtained by the means of Monte Carlo simulation techniques and based on the model outlined in column (1) of Table 4. 


\section{Appendix}

Table A1. Robustness Checks: The Demand for Life Insurance with controls for householdhead share of household income.

\begin{tabular}{|c|c|c|c|c|}
\hline & \multicolumn{4}{|c|}{ Life Insurance } \\
\hline & \multicolumn{4}{|c|}{ Probit } \\
\hline & $(1)$ & (2) & (3) & (4) \\
\hline Immigrant & $\begin{array}{l}-0.126 * * * \\
(0.00690)\end{array}$ & & $\begin{array}{l}-0.108 * * * \\
(0.00731)\end{array}$ & \\
\hline USA & & $\begin{array}{c}-0.0611 * * * \\
(0.0158)\end{array}$ & & \\
\hline England & & $\begin{array}{c}-0.0824 * * * \\
(0.00877)\end{array}$ & & \\
\hline Ireland & & $\begin{array}{c}-0.0727 * * * \\
(0.0190)\end{array}$ & & \\
\hline Scotland & & $\begin{array}{c}-0.0344^{* *} \\
(0.0152)\end{array}$ & & \\
\hline Germany & & $\begin{array}{c}-0.148^{* * *} \\
(0.0285)\end{array}$ & & \\
\hline Italy & & $\begin{array}{c}-0.246 * * * \\
(0.0305)\end{array}$ & & \\
\hline Russia & & $\begin{array}{c}-0.303^{* * *} \\
(0.0140)\end{array}$ & & \\
\hline Sweden & & $\begin{array}{c}-0.168 * * * \\
(0.0374)\end{array}$ & & \\
\hline Austria & & $\begin{array}{c}-0.319 * * * \\
(0.0173)\end{array}$ & & \\
\hline Rest of Europe & & $\begin{array}{c}-0.170 * * * \\
(0.0138)\end{array}$ & & \\
\hline China & & $\begin{array}{c}-0.182 * * * \\
(0.0323)\end{array}$ & & \\
\hline Rest of World & & $\begin{array}{c}-0.0611^{* * *} \\
(0.0158)\end{array}$ & & \\
\hline Male & $\begin{array}{c}0.196 * * * \\
(0.0186)\end{array}$ & $\begin{array}{c}0.202^{* * *} \\
(0.0181)\end{array}$ & $\begin{array}{c}0.200 * * * \\
(0.0183)\end{array}$ & $\begin{array}{c}0.192^{* * *} \\
(0.0187)\end{array}$ \\
\hline Married & $\begin{array}{c}0.132 * * * \\
(0.0103)\end{array}$ & $\begin{array}{c}0.129 * * * \\
(0.0104)\end{array}$ & $\begin{array}{c}0.130 * * * \\
(0.0103)\end{array}$ & $\begin{array}{c}0.137 * * * \\
(0.0101)\end{array}$ \\
\hline Age & $\begin{array}{c}0.0203^{* * *} \\
(0.00168)\end{array}$ & $\begin{array}{c}0.0194 * * * \\
(0.00168)\end{array}$ & $\begin{array}{c}0.0196 * * * \\
(0.00168)\end{array}$ & $\begin{array}{c}0.0210^{* * *} \\
(0.00167)\end{array}$ \\
\hline $\mathrm{Age}^{2}$ & $\begin{array}{c}-0.00023^{* * *} \\
(1.88 \mathrm{e}-05)\end{array}$ & $\begin{array}{c}-0.00022 * * * \\
(1.88 \mathrm{e}-05)\end{array}$ & $\begin{array}{c}-0.00023 * * * \\
(1.88 \mathrm{e}-05)\end{array}$ & $\begin{array}{c}-0.00024^{* * *} \\
(1.88 \mathrm{e}-05)\end{array}$ \\
\hline Dependent children & $\begin{array}{l}0.000953 \\
(0.00166)\end{array}$ & $\begin{array}{c}0.00223 \\
(0.00166)\end{array}$ & $\begin{array}{c}0.00263 \\
(0.00167)\end{array}$ & $\begin{array}{l}-0.000466 \\
(0.00164)\end{array}$ \\
\hline Literate & $\begin{array}{l}0.172 * * * \\
(0.00995)\end{array}$ & $\begin{array}{l}0.162 * * * \\
(0.0102)\end{array}$ & $\begin{array}{l}0.166^{* * *} \\
(0.0102)\end{array}$ & $\begin{array}{l}0.182 * * * \\
(0.00969)\end{array}$ \\
\hline
\end{tabular}




\begin{tabular}{|c|c|c|c|c|}
\hline $\begin{array}{l}\text { Speaks official } \\
\text { language }\end{array}$ & $\begin{array}{c}0.133^{* * *} \\
(0.0127)\end{array}$ & $\begin{array}{c}0.0922 * * * \\
(0.0141)\end{array}$ & $\begin{array}{c}0.111^{* * *} \\
(0.0136)\end{array}$ & $\begin{array}{c}0.123^{* * * *} \\
(0.0130)\end{array}$ \\
\hline Urban agglomeration & $\begin{array}{l}0.123^{* * *} \\
(0.00756)\end{array}$ & $\begin{array}{l}0.125 * * * \\
(0.00756)\end{array}$ & $\begin{array}{l}0.125^{* * *} \\
(0.00757)\end{array}$ & $\begin{array}{l}0.124 * * * \\
(0.00749)\end{array}$ \\
\hline Household income & $\begin{array}{l}0.0631^{* * *} \\
(0.0102)\end{array}$ & $\begin{array}{c}0.0647 * * * \\
(0.0100)\end{array}$ & $\begin{array}{c}0.0619 * * * \\
(0.0106)\end{array}$ & $\begin{array}{c}0.0624 * * * \\
(0.0100)\end{array}$ \\
\hline (Household income) $^{2}$ & $\begin{array}{c}-0.00202 * * * \\
(0.000714)\end{array}$ & $\begin{array}{c}-0.00207 * * * \\
(0.000703)\end{array}$ & $\begin{array}{c}-0.00196 * * * \\
(0.000747)\end{array}$ & $\begin{array}{c}-0.00202^{* * *} \\
(0.000702)\end{array}$ \\
\hline $\begin{array}{l}\text { Household-head share } \\
\text { of household income }\end{array}$ & $\begin{array}{c}0.196 * * * \\
(0.0168)\end{array}$ & $\begin{array}{c}0.188 * * * \\
(0.0167)\end{array}$ & $\begin{array}{c}0.191^{* * *} \\
(0.0172)\end{array}$ & $\begin{array}{c}0.196 * * * \\
(0.0166)\end{array}$ \\
\hline Farmer & $\begin{array}{l}-0.0284 \\
(0.0179)\end{array}$ & $\begin{array}{l}-0.0260 \\
(0.0179)\end{array}$ & $\begin{array}{l}-0.0248 \\
(0.0180)\end{array}$ & $\begin{array}{c}-0.0380^{* *} \\
(0.0177)\end{array}$ \\
\hline Insurance supply & $\begin{array}{c}0.136^{* * *} \\
(0.0202)\end{array}$ & $\begin{array}{c}0.0753^{* * *} \\
(0.0215)\end{array}$ & $\begin{array}{c}0.115^{* * * *} \\
(0.0210)\end{array}$ & $\begin{array}{c}0.0677^{* * *} \\
(0.0191)\end{array}$ \\
\hline Anglican & & & $\begin{array}{l}-0.00520 \\
(0.0102)\end{array}$ & \\
\hline Methodist & & & $\begin{array}{c}0.0551^{* * * *} \\
(0.0109)\end{array}$ & \\
\hline Baptist & & & $\begin{array}{c}0.0187 \\
(0.0146)\end{array}$ & \\
\hline Presbyterian & & & $\begin{array}{c}0.0546 * * * \\
(0.0107)\end{array}$ & \\
\hline Protestant & & & $\begin{array}{c}0.0285 \\
(0.0428)\end{array}$ & \\
\hline Lutheran & & & $\begin{array}{c}-0.0604^{* * *} \\
(0.0209)\end{array}$ & \\
\hline Jewish & & & $\begin{array}{c}-0.225^{* * *} \\
(0.0209)\end{array}$ & \\
\hline Other & & & $\begin{array}{l}-0.0171 \\
(0.0150)\end{array}$ & \\
\hline Immigrant * East & & & & $\begin{array}{c}-0.0714 * * * \\
(0.0274)\end{array}$ \\
\hline Immigrant * Center & & & & $\begin{array}{l}-0.109 * * * \\
(0.00811)\end{array}$ \\
\hline Immigrant * West & & & & $\begin{array}{c}-0.152^{* * *} \\
(0.0121)\end{array}$ \\
\hline East & & & & $\begin{array}{l}-0.144 * * * \\
(0.00945)\end{array}$ \\
\hline West & & & & $\begin{array}{c}-0.0590 * * * \\
(0.0119)\end{array}$ \\
\hline Province controls & yes & yes & yes & \\
\hline Occupation controls & yes & yes & yes & yes \\
\hline Observations & 30,665 & 30,665 & 30,665 & 30,665 \\
\hline Pseudo-R ${ }^{2}$ & 0.132 & 0.136 & 0.136 & 0.128 \\
\hline
\end{tabular}


Note: Robust standard errors in parentheses. Omitted categories - Country (column

2): Canada, Religion: Roman Catholic, Region: Center.

$* * * \mathrm{p}<0.01, * * \mathrm{p}<0.05, * \mathrm{p}<0.1$.

Table A2. The Demand for Life Insurance and Immigration by Province.

\begin{tabular}{|c|c|}
\hline & $\begin{array}{c}\text { Life } \\
\text { Insurance }\end{array}$ \\
\hline & $\begin{array}{c}\text { Probit } \\
\text { (1) }\end{array}$ \\
\hline Immigrant $*$ provinceNS & $\begin{array}{c}-0.0747 * * \\
(0.0324)\end{array}$ \\
\hline Immigrant $*$ provincePEI & $\begin{array}{l}-0.175 \\
(0.117)\end{array}$ \\
\hline Immigrant $*$ provinceNB & $\begin{array}{l}0.00556 \\
(0.0445)\end{array}$ \\
\hline Immigrant * provinceQC & $\begin{array}{c}-0.132 * * * \\
(0.0137)\end{array}$ \\
\hline Immigrant $*$ provinceON & $\begin{array}{l}-0.110^{* * *} \\
(0.00848)\end{array}$ \\
\hline Immigrant $*$ provinceMB & $\begin{array}{c}-0.192^{* * *} \\
(0.0154)\end{array}$ \\
\hline Immigrant * provinceSK & $\begin{array}{c}-0.163^{* * *} \\
(0.0219)\end{array}$ \\
\hline Immigrant * provinceAB & $\begin{array}{c}-0.148^{* * *} \\
(0.0218)\end{array}$ \\
\hline Immigrant * provinceBC & $-0.112^{* * *}$ \\
\hline
\end{tabular}


(0.0183)

Married

$0.129 * * *$

(0.00852)

Male

$0.213^{* * *}$

(0.0136)

Age

$0.0209 * * *$

(0.00146)

Age2

$-0.00025^{* * *}$

(1.62e-05)

Dependent children

$-0.000536$

(0.00146)

Literate

$0.183^{* * *}$

$(0.00848)$

Speaks official language

$0.137^{* * *}$

$(0.0112)$

Urban agglomeration

$0.112^{* * *}$

(0.00689)

Household income

$0.0284^{* * *}$

$(0.00531)$

(Household income)2

$-0.00104 * * *$

$(0.000404)$

occs2

$0.0787 * * *$

$(0.0155)$

occs3

$0.122^{* * *}$

(0.0195)

occs4

$0.182^{* * *}$

(0.0181) 


\begin{tabular}{|c|c|}
\hline occs5 & $\begin{array}{l}-0.0236 \\
(0.0297)\end{array}$ \\
\hline occs6 & $\begin{array}{l}0.118^{* * *} \\
(0.0177)\end{array}$ \\
\hline occs7 & $\begin{array}{l}0.203^{* * *} \\
(0.0163)\end{array}$ \\
\hline occs8 & $\begin{array}{l}0.197^{* * *} \\
(0.0173)\end{array}$ \\
\hline occs9 & $\begin{array}{c}0.0625^{* * *} \\
(0.0214)\end{array}$ \\
\hline occs 10 & $\begin{array}{c}0.298 * * * \\
(0.0194)\end{array}$ \\
\hline occs11 & $\begin{array}{c}0.263^{* * *} \\
(0.0156)\end{array}$ \\
\hline occs12 & $\begin{array}{c}0.215^{* * *} \\
(0.0156)\end{array}$ \\
\hline Farmer & $\begin{array}{c}0.0144 \\
(0.0145)\end{array}$ \\
\hline Insurance supply & $\begin{array}{c}0.127^{* * *} \\
(0.0191)\end{array}$ \\
\hline provinceAB & $\begin{array}{c}-0.0644^{* * *} \\
(0.0197)\end{array}$ \\
\hline provinceBC & $\begin{array}{c}-0.122^{* * *} \\
(0.0149)\end{array}$ \\
\hline provinceMB & $\begin{array}{c}0.0361^{* *} \\
(0.0168)\end{array}$ \\
\hline provinceNB & $-0.0999 * * *$ \\
\hline
\end{tabular}


$(0.0121)$

provinceNS

$-0.202 * * *$

$(0.00895)$

provincePEI

$-0.151^{* * *}$

$(0.0258)$

provinceQC

$-0.0762 * * *$

$(0.00755)$

provinceSK

$-0.0477^{* *}$

$(0.0194)$

Observations

37,874

Pseudo-R2

0.126

Note: Robust standard errors in parentheses. $* * *$

$$
\mathrm{p}<0.01,{ }^{* *} \mathrm{p}<0.05,{ }^{*} \mathrm{p}<0.1 \text {. }
$$


Table A3. Robustness Checks: Sub-sampling by Region and Type of Settlement.

\begin{tabular}{|c|c|c|c|c|c|c|}
\hline & \multicolumn{6}{|c|}{ Life Insurance } \\
\hline & \multicolumn{6}{|c|}{ Probit } \\
\hline & (1) & (2) & (3) & (4) & (5) & (6) \\
\hline & & & Western & Eastern & & \\
\hline & Quebec & Ontario & Provinces & Province & Urban & Rural \\
\hline \multirow[t]{2}{*}{ Immigrant } & $-0.162^{* * *}$ & $-0.121 * * *$ & $-0.142 * * *$ & $-0.0368 *$ & $-0.160 * * *$ & $-0.0545^{* * *}$ \\
\hline & $(0.0160)$ & (0.00987) & $(0.0111)$ & $(0.0190)$ & $(0.00779)$ & $(0.00935)$ \\
\hline \multirow[t]{2}{*}{ Male } & $0.247 * * *$ & $0.244^{* * *}$ & $0.184 * * *$ & $0.0988 * * *$ & $0.235 * * *$ & $0.162^{* * *}$ \\
\hline & $(0.0258)$ & $(0.0247)$ & (0.0239) & $(0.0306)$ & $(0.0207)$ & $(0.0137)$ \\
\hline \multirow[t]{2}{*}{ Married } & $0.103^{* * *}$ & $0.138^{* * *}$ & $0.128 * * *$ & $0.0963 * * *$ & $0.141^{* * *}$ & $0.0996 * * *$ \\
\hline & $(0.0200)$ & $(0.0158)$ & $(0.0136)$ & $(0.0173)$ & $(0.0133)$ & $(0.00882)$ \\
\hline \multirow[t]{2}{*}{ Age } & $0.0130 * * *$ & $0.0232 * * *$ & $0.0221 * * *$ & $0.0215^{* * *}$ & $0.0180 * * *$ & $0.0203 * * *$ \\
\hline & $(0.00293)$ & $(0.00226)$ & (0.00339) & $(0.00316)$ & $(0.00192)$ & $(0.00185)$ \\
\hline \multirow[t]{2}{*}{ Age2 } & $-0.00018^{* * *}$ & $-0.00026 * * *$ & $-0.00026 * * *$ & $-0.00027 * * *$ & $0.00021^{* * *}$ & $-0.00025 * * *$ \\
\hline & (3.31e-05) & $(2.45 e-05)$ & $(4.00 \mathrm{e}-05)$ & $(3.41 \mathrm{e}-05)$ & $(2.14 \mathrm{e}-05)$ & $(2.03 e-05)$ \\
\hline \multirow[t]{2}{*}{$\begin{array}{l}\text { Dependen } \\
\text { children }\end{array}$} & $0.00489 *$ & -0.00281 & 0.00161 & -0.00371 & 0.00138 & -0.00205 \\
\hline & $(0.00252)$ & $(0.00268)$ & $(0.00335)$ & $(0.00296)$ & $(0.00201)$ & $(0.00179)$ \\
\hline \multirow[t]{2}{*}{ Literate } & $0.181^{* * *}$ & $0.207^{* * *}$ & $0.200 * * *$ & $0.0803 * * *$ & $0.172 * * *$ & $0.147 * * *$ \\
\hline & $(0.0132)$ & (0.0193) & $(0.0211)$ & $(0.0172)$ & $(0.0144)$ & $(0.00808)$ \\
\hline Speaks official & $0.200 * * *$ & $0.0931 * * *$ & $0.202 * * *$ & 0.0299 & $0.153^{* * *}$ & $0.108 * * *$ \\
\hline language & $(0.0348)$ & (0.0192) & $(0.0158)$ & (0.0239) & $(0.0166)$ & $(0.0117)$ \\
\hline
\end{tabular}


Urban

$$
0.105^{* * *} \quad 0.146^{* * *} \quad 0.0606^{* * *} \quad 0.0648^{* * *}
$$

$$
(0.0130) \quad(0.0119) \quad(0.0141) \quad(0.0144)
$$

Household

$$
\begin{array}{llllll}
0.0345^{* * *} & 0.0330^{* * *} & 0.0360^{* * *} & 0.110^{* * *} & 0.0312^{* * *} & 0.0306^{* * *}
\end{array}
$$

income

$$
\begin{array}{llllll}
(0.00670) & (0.00765) & (0.00522) & (0.0135) & (0.00470) & (0.00471)
\end{array}
$$

(Household

income)2

$$
\begin{array}{llll}
-0.00077 * * * & -0.00239 * * * & -0.00168 * * * & -0.00799 * * *
\end{array}
$$

$0.000855^{* *}$

$-0.00151^{* * *}$

$$
\begin{array}{llllll}
(0.000264) & (0.000859) & (0.000323) & (0.00206) & (0.000389) & (0.000285)
\end{array}
$$

Farmer

$\begin{array}{lccccc}-0.0554^{*} & 0.0151 & 0.0674 * * & 0.0111 & 0.0141 & 0.0205 \\ (0.0319) & (0.0220) & (0.0318) & (0.0321) & (0.0403) & (0.0128)\end{array}$

Insurance

0.0619*

$0.144^{* * *}$

$0.407^{* * *}$

$-0.0410$

$0.139 * * *$

$0.0957 * * *$

supply
(0.0343)
(0.0289)
(0.0562)
(0.0576)
(0.0228)
(0.0262)

Province

controls

$$
\text { yes }
$$

yes

yes

yes

Occupation

controls

$$
\text { yes }
$$

yes

yes

yes

yes

yes

Observations

10,337

14,638

7,781

5,118

22,976

14,898

Note: Robust standard errors in parentheses. ${ }^{* * *} \mathrm{p}<0.01,{ }^{* *} \mathrm{p}<0.05,{ }^{*} \mathrm{p}<0.1$. 